\title{
DEVELOPMENT OF YOUTH LEADERSHIP LIFE SKILLS OF TEXAS YOUTH AS SAN ANTONIO LIVESTOCK EXPOSITION SCHOOL TOUR GUIDES
}

\author{
A Thesis \\ by \\ LAURA ANN REAL \\ Submitted to the Office of Graduate Studies of \\ Texas A\&M University \\ in partial fulfillment of the requirements for the degree of \\ MASTER OF SCIENCE
}

December 2004

Major Subject: Agricultural Education 


\title{
DEVELOPMENT OF YOUTH LEADERSHIP LIFE SKILLS OF TEXAS YOUTH AS SAN ANTONIO LIVESTOCK EXPOSITION SCHOOL TOUR GUIDES
}

\author{
A Thesis \\ by \\ LAURA ANN REAL \\ Submitted to Texas A\&M University \\ in partial fulfillment of the requirements \\ for the degree of \\ MASTER OF SCIENCE
}

Approved as to style and content by:

\begin{tabular}{c}
\hline $\begin{array}{c}\text { Julie Harlin } \\
\text { (Chair of Committee) }\end{array}$ \\
\hline $\begin{array}{c}\text { Barry Boyd } \\
\text { (Member) }\end{array}$
\end{tabular}

\begin{tabular}{c}
\hline $\begin{array}{c}\text { Chris Skaggs } \\
\text { (Member) }\end{array}$ \\
\hline Glen Shinn \\
(Head of Department)
\end{tabular}

December 2004

Major Subject: Agricultural Education 


\begin{abstract} Exposition School Tour Guides. (December 2004)

Laura Ann Real, B.S., Texas A\&M University

Chair of Advisory Committee: Dr. Julie Harlin
\end{abstract}

Development of Youth Leadership Life Skills of Texas Youth as San Antonio Livestock

Many youth organizations, including 4-H, FFA, and Family, Career, and Community Leaders of America (FCCLA), offer countless opportunities for their members to learn and further develop leadership life skills that are important in becoming contributing members of society as adults. The purpose of this study was to determine if Texas 4-H, FFA, and FCCLA members were developing leadership life skills as school tour guides at the San Antonio Livestock Exposition. Additionally, demographic characteristics were evaluated to determine which of these characteristics affected leadership life skills development. Demographic characteristics evaluated included gender, age, ethnicity, youth organization membership, years of membership, years of experience as a school tour guide, and previous leadership skills training.

The target population was Texas 4-H, FFA, and FCCLA members who served as school tour guides at the San Antonio Livestock Exposition. School tour guides referred to the 4-H, FFA, FCCLA members who imparted their personal knowledge of agriculture to elementary-aged students from San Antonio and surrounding area schools that requested an educational tour at the San Antonio Livestock Exposition. 
There were 1,691 school tour guides on the days of February 9, 10, 11, 12, 13, 17, and 18, 2004. All school tour guides returning for the afternoon exit-meeting during the 2004 San Antonio Livestock Exposition were asked to complete the questionnaire. The questionnaire was a 28-item survey instrument that was based on the scales: Working with Groups, Understanding Self, Communicating, Making Decisions, and Leadership.

Conclusions showed school tour guides had developed leadership life skills. The most influential demographic characteristics were gender, previous leadership experiences, and ethnicity. Females and those participants who had had previous leadership experiences had stronger perceptions of their leadership life skills. In addition, African Americans, Asian Americans, Hispanics, and Anglos all had stronger perceptions of their leadership life skills when compared to Native Americans.

As a result of this study, the researcher recommends that youth should be encouraged to participate as school tour guides at the San Antonio Livestock Exposition. School tour guides had developed leadership life skills. In addition, youth should also be encouraged to participate in other leadership-development activities through other programs to further develop and enhance their leadership life skills. 


\section{DEDICATION}

This is for my family

I never would have been able to make it this far without you.

You are the reason I am where I am today. 


\section{ACKNOWLEDGMENTS}

There is no way that this piece of work would have ever come to light without the help of so many. First, I have to thank the members of my committee. Dr. Julie Harlin, you have truly helped me make sense of what was in front of me. You are someone I look up to and I'm glad I have had the opportunity to work with you. Dr. Barry Boyd, thank you for allowing me to knock on your door at any time for some clarification about where I was going with this. Dr. Chris Skaggs, what can I say? I have known you for a long time and you have always been someone I consider a mentor and friend. I will miss the "advising” sessions in your office. They are something that I will always treasure.

Dr. Gary Briers, you were a lifesaver! I thought I had learned something in statistics, but I soon realized it was not what I needed. Thanks for the SPSS and statistics sessions at random in your office. I also have to be sure to send a bit of appreciation to Dr. Tracy Rutherford and Dr. Gary Wingenbach. You two helped me get started in AGED 689 last summer. Thanks for having some understanding with a new grad student who was pretty green when it came to research and writing!

Ryan Huebinger and Sam Cunningham, you two should be rewarded! Thanks for pushing me to go back and work every morning (or sometimes afternoon). You two have been my inspiration while writing. You were always good at providing those needed “study breaks,” whether they were email wars across campus or a lunch break or even the lake. I'm glad that we have become so close and hope that it stays that way. 
Kristin Voges, you will be a friend forever. We have been through so much and have been all over the country together. Life will be strange without you. You have always been a source of motivation for me. Believe it or not, you helped me decide where to go with my degree.

Mom and Dad, there is absolutely no way that I would be anywhere close to where I am today without the two of you. You two are the greatest parents and the best role models ever. There is no way that I could ever "repay" you - maybe one day, just not right now! I just hope that one day I can be as happy and successful in life as you are. I love you so much. Oma and Opie, you two have always been a source of motivation for me. You have helped me realize how truly lucky I am. Thank you for showing me what being a family is all about. Russell, you are a pretty good roommate and an okay "little" brother who put up with my late nights and short fuse while working on all of this. Good luck with school - just remember you have to study some, too!

Daryl, Sue, Kyle, and my soon-to-be niece, Grace - I really couldn’t have asked for a better brother and sister-in-law. You two have always served as a guide for me. Daryl, thanks for putting up with my millions of questions. Sue, you truly were and continue to be an inspiration to me. I don't know how you completed your master's while working and having Mr. Kyle with Miss Grace on the way. Kyle, you always brightened my day while I was working; all I had to do was look at your picture and it brought me a smile. Now, take care of your new little sister Grace, when she gets here. I would be remiss if I didn't thank the San Antonio Livestock Exposition and the School Tours Committee. To Glen Alan Phillips and Jill Fey, thanks for letting me run 
off each day to collect my data. I don't know what I would have done otherwise. Karla Friesenhahn, you are awesome! You helped me more than you will ever know.

To the Ladies of Scoates Hall: Kimberly Wright-Thomas, Kayla KohlsRathmann, Christyn Cochran, Elisa Noble, and Holly Kasperbauer, thank you for being there for me. You girls were always ready to lend an ear while I stressed over all of this. It really means a lot to me! 


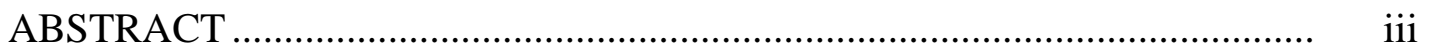

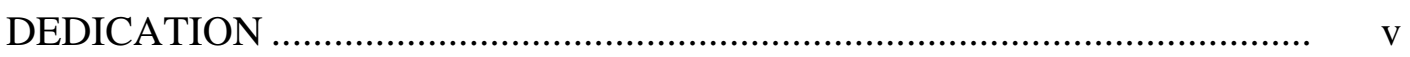

ACKNOWLEDGMENTS .......................................................................... vi

TABLE OF CONTENTS …………………………............................... ix

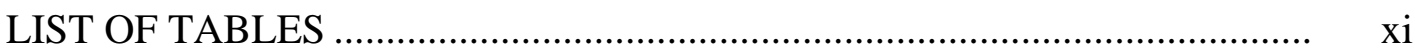

CHAPTER

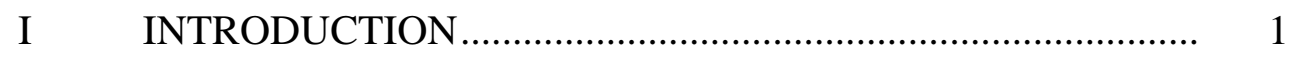

Background of the Study................................................. 1

Theoretical Base for the Study ……….............................. 2

Statement of the Problem ................................................. 3

Purpose and Objectives .................................................... 4

II REVIEW OF LITERATURE................................................... 5

Experiential Youth Leadership Organizations ................ 5

Definition of Leadership .................................................. 7

Youth Leadership Life Skills Development (YLLSD) ... 8

Summary of Youth Leadership Life Skills Development 16

Texas 4-H Program ........................................................ 17

Texas FFA Association .................................................. 18

Texas Association of Family, Career, and Community

Leaders of America .......................................................... 19

School Tour Guides........................................................ 20

San Antonio Livestock Exposition School Tours

Program ..................................................................... 20

Summary of Literature Review ...................................... 21

Purpose of the Study ........................................................ 22

III METHODOLOGY ............................................................. 23

Purpose and Objectives ................................................ 23

Research Design ............................................................... 23 
CHAPTER Page

Population and Sample............................................... 24

Letters to Teachers and Parents.................................... 24

Instrument............................................................... 25

Data Collection and Analysis .................................... 27

IV $\quad$ FINDINGS AND DISCUSSION .......................................... 29

Purpose and Objectives ............................................. $\quad 29$

Description of Sample ................................................ 29

Profile of Instrument ..................................................... 30

Findings Related to Objective One .............................. 31

Findings Related to Objective Two.............................. 34

Findings Related to Objective Three............................ 36

V SUMMARY, CONCLUSIONS, AND

RECOMMENDATIONS ..................................................... 48

Summary .......................................................... 48

Conclusions and Implications .................................... 50

Conclusions Related to Objective One.......................... 50

Conclusions Related to Objective Two......................... 51

Conclusions Related to Objective Three....................... 52

Programmatic Recommendations.................................. 53

Recommendations for Additional Research.................. 54

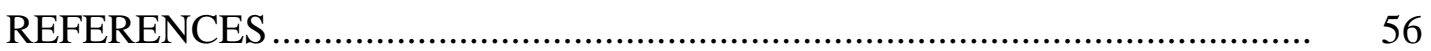

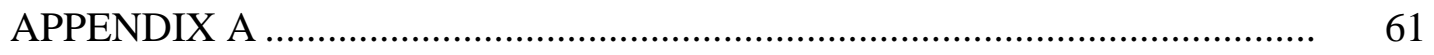

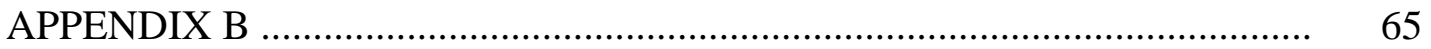

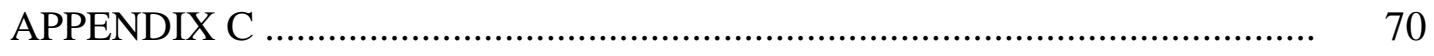

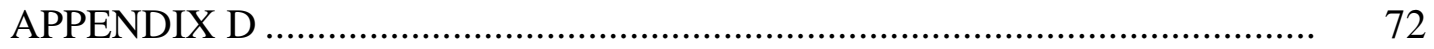

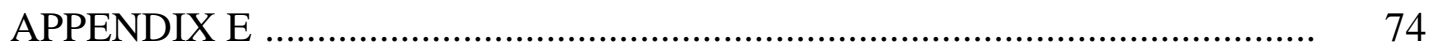

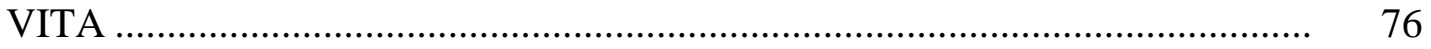




\section{LIST OF TABLES}

TABLE Page

1 Reliability Coefficients (Alpha) for Each Measurement Scale.............. 27

2 Intercorrelations of Leadership Life Skills Scales .............................. 31

3 Selected Demographic Characteristics of School Tour Guides ............. 32

4 School Tour Guides’ Self-Perceptions of Youth Leadership

Life Skills Development.................................................................... 35

5 T-test for Independent Samples: Gender and Youth Leadership

Life Skills Development.

6 Pearson Correlation Coefficient between Age and Leadership Life Skills Development....................................................................

7 Analysis of Variance of Scales Measuring Leadership Life Skills by Ethnicity

8 Analysis of Variance of Scales Measuring Leadership Life Skills Development by Organization Membership

9 Spearman's rho Correlation Coefficient between Years as a Member of Organization and Leadership Life Skills Development.

10 Pearson Correlation Coefficient between Years as a School Tour Guide and Leadership Life Skills Development

11 Pearson Correlation Coefficient between Number of Previous Leadership Experiences and Leadership Life Skills Development of School Tour Guides.

12 Pearson Correlation Coefficient between Whether the Student Had Previous Leadership Experiences and Leadership Life Skills Development of School Tour Guides

13 T-test for Independent Samples: Agricultural or Non-Agricultural Previous Leadership Experiences and Leadership Life Skills Development 


\section{CHAPTER I}

\section{INTRODUCTION}

\section{Background of the Study}

Since the beginning of 4-H, FFA, and Family, Career, and Community Leaders of America (FCCLA) programs, the goal has been to produce productive members of society through the development of leadership life skills in the youth enrolled in their programs. Youth organizations offer countless opportunities for members to learn and develop leadership life skills that are important in becoming contributable members of society as adults. 4-H, FFA, and FCCLA are just three of many youth organizations available. Members of these organizations can participate in numerous types of projects ranging from family and consumer sciences to agriculture, public speaking, and leadership. These programs employ the motto of "learning by doing.” By participating in hands-on experiences, youth are better able to learn and apply these necessary skills to their lifestyles (Boyd, 1991; Wingenbach \& Kahler, 1997; Friesenhahn, 1999; and Howard, 2001).

Youth leadership life skills development (YLLSD) is defined as “development of life skills necessary to perform leadership functions in real life” (Miller, 1976, p. 2). Townsend (1981) classified leadership and life skills into five constructs: working with groups, understanding self, communicating, making decisions, and leadership.

This thesis follows the style and format of the Journal of Agricultural Education. 
According to Seevers, Dormody, and Clason (1995), YLLSD can be categorized into seven sub-domains: communication skills, decision-making skills, skills in getting along with others, learning skills, management skills, skills in understanding self, and skills in working with groups.

\section{Theoretical Base for the Study}

The amount of previous research in the literature regarding the development of leadership life skills is abundant. Many studies have evaluated the effectiveness of youth development programs, such as 4-H, FFA, and FCCLA (Boyd, Herring, and Briers, 1992; Friesenhahn, 1997; and Howard, 2001). Other studies have evaluated adult populations after participation in these organizations or after coursework in a related field (Thorp, Cummins, and Townsend, 1998; and Viegas, 1997).

Leadership education and development has been an integral part of most experiential youth organizations. Many make the assumption that these organizations are successful in their goals of developing these leadership life skills. Nevertheless, the question remains as to whether these perceptions are really true? Recently, many youth organizations have tried to confirm the effectiveness of their programs for many different reasons, such as budget constraints and possible disbanding of certain activities.

Experiential youth organizations have been successful at developing leadership life skills in youth that participate in their programs. Boyd et al. (1992) found that youth involved in 4-H programs rated themselves as having a higher level of leadership life skills development than those not involved. Howard (2001) reported similar results in his

study. Brick (2002) showed that FFA members were developing leadership life skills at a leadership conference and created a FFA Member Leadership Model. Thorp et al. (1998) 
indicated that collegiate women were also able to develop leadership life skills through coursework and activities. Brannon, Holley, and Key (1989) indicated that youth in a vocational agricultural program were more likely to be involved in community activities as adults.

\section{Statement of the Problem}

Many researchers have studied leadership life skills through overall involvement of experiential youth leadership organizations and indicated that youth truly are developing these skills and they are retaining them into their adulthood (Boyd et al., 1992; Dormody \& Seevers, 1994; Seevers \& Dormody, 1994; Wingenbach \& Kahler, 1997; Howard, 2001; and Rutherford, Townsend, Briers, Cummins, and Conrad, 2002). However, none of these studies have specifically addressed whether participation as a school tour guide at San Antonio Livestock Exposition impacts development of youth leadership life skills.

This researcher will look at Texas 4-H, FFA, and FCCLA members who serve as school tour guides at San Antonio Livestock Exposition. School tour guides impart their personal knowledge of agriculture to elementary-age students from San Antonio and surrounding area schools who request an educational tour at the San Antonio Livestock Exposition. This study will examine Texas 4-H, FFA, and FCCLA members and determine if they develop youth leadership life skills from their participation as school tour guides. 


\section{Purpose and Objectives}

The purpose of this study was to determine if Texas 4-H, FFA, and FCCLA members developed youth leadership life skills as school tour guides. The following objectives were set to guide this study.

1. Describe the demographic characteristics of school tour guides at the 2004 San Antonio Livestock Exposition.

2. Determine if Texas 4-H, FFA, and FCCLA members developed leadership life skills as school tour guides according to the Leadership Skills Inventory.

3. Determine which demographic variables affected youth leadership life skills development.

For the purpose of this study, leadership life skills referred to the five scales measured by the Leadership Skills Inventory: Working with Groups, Understanding Self, Communicating, Making Decisions, and Leadership. Also, for the purpose of this study, demographic variables were defined as gender, age, ethnicity, youth organization membership, years of membership, years of experience as a school tour guide, and previous leadership skills training. 


\section{CHAPTER II}

\section{REVIEW OF LITERATURE}

This literature review provides a foundation of previous research regarding the relationship between youth leadership life skills development (YLLSD) and participation in experiential youth leadership organizations. An explanation of experiential youth leadership organizations is discussed, followed by a definition of leadership and then, more specifically, youth leadership life skills development. Three specific agricultural youth organizations will also be discussed. The final section provides a definition of school tour guides. The literature review was divided into seven sections:

1. Experiential Youth Leadership Organizations

2. Definition of Leadership

3. Youth Leadership Life Skills Development (YLLSD)

4. Texas 4-H

5. Texas FFA

6. Texas Family, Career, and Community Leaders of America (FCCLA)

7. School Tour Guides

\section{Experiential Youth Leadership Organizations}

Leadership education has been an integral part of experiential youth leadership organizations. Three of these organizations are 4-H, FFA, and Family, Career, and Community Leaders of America (FCCLA). The 4-H program is the youth component of the Cooperative Extension Service, which serves youth ages 8 to 19 (Texas Agricultural Extension Service, 2001). The National FFA Organization is an agricultural education program that serves high school youth (National FFA Organization, 2003a). FCCLA is 
national vocational organization for high school students interested in family and consumer sciences education (Family, Career, and Community Leaders of America [FCCLA], 2003). By their very nature and purpose, these organizations focus on the development of youth through various activities. Most assume that these organizations are successful at developing leadership life skills through the programs and opportunities they offer to their members. Nevertheless, is this perception true? Recently, organizations such as these have focused on the effectiveness of the leadership training they offer to their members to provide accountability for and to continually improve their respective programs (Dodson, 1996; Wingenbach \& Kahler, 1997; Friesenhahn, 1999; Howard, 2001; and Rutherford, Townsend, Briers, Cummins, \& Conrad, 2002).

Carter and Spotanski (1989) studied the relationship between student experiences and their self-perceived leadership development levels from a group of students in three Iowa high schools over a period of three years. A total of 3,437 students in grades 9 to 12 were selected. The instrument was designed to measure students' perceptions of their personal development and leadership skills. The instrument included ten scales: group drive, cohesiveness, productivity, achievement, attitude toward group work, degree of attainment of leadership, self-confidence, cooperation, citizenship, and personal development.

Carter and Spotanski (1989) found that students who served as an officer rated all ten scales significantly higher than those who had not. Students who served as a committee chair in a student or community organization rated all 10 scales higher than those who had not, and students who received formal leadership training rated 9 of the 10 scales significantly higher than those who did not. 


\section{Definition of Leadership}

Leadership can be defined in many ways. There are as many definitions of leadership as there are those who have tried to define leadership. Cronin (in Rosenbach and Taylor, 1993) states that “so much of leadership is intangible, you can’t possibly define all the parts” (p. 9). Most definitions are vague and many authors attempt to describe only the characteristics and attributes of a leader.

Lundy (1986) viewed leadership as relationships between people. In order to be a leader, he or she has to have followers. Cronin (in Rosenbach and Taylor, 1993) also viewed leadership as a relationship between people. Specifically, Cronin states "leaders are people who perceive what is needed and what is right and know how to mobilize people and resources to accomplish mutual goals” (p. 12). This is similar to the definition used by Northouse (2004) that "leadership is a process whereby an individual influences a group of individuals to achieve a common goal” (p. 3). Northouse (2004) further explains this definition. A process is a transactional event where both the leader and follower are affected. Influence is described as how a leader affects the followers, and groups are the context in which leadership exists. Finally, the term goals is used to describe the leader directing towards accomplishing an end together.

Cronin and Northouse's views of leadership are in agreement with Kouzes and Posner’s (1995) definition of leadership, “the art of mobilizing others to want to struggle for shared aspirations” (p. 30). Kouzes and Posner point out that the most significant words in the definition are want to. This implies an internal motivation, an inner desire, or simply a voluntary action. This intrinsic desire is what separates leaders from managers. Managers more often use extrinsic rewards to get results from subordinates. 
Many others also view a similar difference between leaders and managers (Cronin in Rosenbach and Taylor, 1993; Northouse, 2004; and Lundy, 1986).

Holder and Wilkinson (2001) describe leadership as “an awe-inspiring trait that’s hard to define yet easy to see in action. Some people seem to be born with it, but it's something we must all learn and develop with practice.” Being born with leadership characteristics, or the trait theory, is an older paradigm of leadership and more recently, has been discounted by many (Northouse, 2001; Kouzes and Posner, 1995; and Cronin in Rosenbach and Taylor, 1993).

\section{Youth Leadership Life Skills Development (YLLSD)}

Holder and Wilkinson (2001) state that to be a good leader, one needs to develop several types of skills that can be used in many ways throughout life; thus, they are called leadership life skills. They define seven leadership life skill areas: understanding self, communicating, getting along with others, learning to learn, making decisions, managing, and working with groups. These seven areas match the seven constructs of youth leadership life skill development as described by Seevers, Dormody, and Clason (1995). These seven constructs where originally based on work of Miller (1976) who defined youth leadership life skills as “development of life skills necessary to perform leadership functions in real life” (p. 2). Townsend and Carter (1983) also studied youth leadership life skills and provide five scales of leadership: working with groups, understanding self, making decisions, communication, and leadership.

Many researchers have investigated the relationships between involvement in 4-H and FFA activities and development of leadership life skills. The following studies specifically address these relationships. 
Boyd et al. (1992) compared YLLSD of Texas 4-H members to non-members, and examined the relationship between YLLSD and level of participation in 4-H. The sample included 4-H members from 19 randomly selected Texas counties and nonmembers from 28 randomly selected Texas schools. The instrument utilized was the Leadership and Personal Development Inventory developed at Iowa State University, which groups statements into five categories: working with groups, understanding self, communicating, making decisions, and leadership.

Boyd et al. (1992) found that Texas 4-H members' perceptions of their YLLSD were significantly higher than the perceptions of non-members. In addition, the researchers found that Texas 4-H members' level of YLLSD increased as their level of participation in 4-H activities increased.

Determining predictors of YLLSD of youth in Arizona, Colorado, and New Mexico was the objective of two similar studies conducted by Seevers and Dormody (1994) of senior 4-H members and by Dormody and Seevers (1994) of FFA members. They attempted to determine predictors of YLLSD from the independent variables of participation in FFA leadership activities, achievement expectancy, self-esteem, years in FFA, age, ethnicity, gender, and place of residence. Data were collected from Arizona, Colorado, and New Mexico FFA members $(n=256)$. A proportional stratified sample was used to ensure representation of each state.

The two major findings of the Dormody \& Seevers (1994) study were that three variables - achievement expectancy, participation in FFA leadership activities, and gender - explained statistically significant amounts of variance in YLLSDS scores; and YLLSD was not related to self-esteem, years in FFA, age, ethnicity, or place of 
residence. Achievement expectancy explained 14\% of the variance, participation in FFA leadership activities explained $2.3 \%$ of the variance, and gender explained $0.9 \%$ of the variance in the YLLSDS scores.

The findings of this study are in contrast to the results of the similar study conducted by Seevers and Dormody (1994) of 4-H members. Four variables attributed to variance in YLLSDS scores: participation in leadership activities (12.6\%), ethnicity (3.3\%), achievement expectancy (1.9\%), and gender (1.7\%).

From these conclusions, Seevers and Dormody (1994) raised the following questions: "Is 4-H more leadership oriented in its activities than FFA? Is FFA more achievement oriented in its activities than 4-H?” (p.68).

Using an adapted version of the YLLSDS developed by Seevers et al. (1995), Wingenbach and Kahler (1997) explored the relationship between Iowa FFA members’ self-perceived leadership and life skills development and their participation in youth leadership activities. A simple random sample of Iowa FFA students yielded 282 usable questionnaires. The instrument includes seven sub-domains of YLLSDS: communication skills, decision-making skills, skills for getting along with others, learning skills, management skills, skills in understanding self, and skills in working with groups.

Wingenbach and Kahler (1997) found "the strongest statistically significant relationship existed between [YLLSD] and FFA leadership activities” (p.23). Other factors that related to YLLSD were years of membership in FFA, age, jobs, achievement expectancy, club officer, church groups, and class officer. These researchers also found that the female FFA members participating in "this study significantly outscored their 
male counterparts on the YLLSDS section” (p. 23) of the questionnaire (Wingenbach \& Kahler, 1997).

White (1997) set out to ascertain the effectiveness of family and consumer science programs in Iowa high schools. A sample of 144 Iowa schools was selected to answer the 38-question survey including demographic and Likert-type scale questions. The intent of the questions was to measure the attainment of the state-mandated minimum competencies for family and consumer science. Specifically related to leadership, White's study indicated that the longer students were enrolled in a family and consumer science course the more aware they were of their leadership abilities.

Howard (2001) set out to generate defensible data showing the positive effects of Texas 4-H and to determine if the level of effectiveness varied based on selected demographic variables. Specifically, the study determined if $4-\mathrm{H}$ promotes a positive feeling of a member's self-worth, if 4-H instills a sense of importance for community service, if 4-H members are gaining decision-making skills, if members have a sense of belonging and peer acceptance, and if selected demographics have a bearing on the program's effectiveness. A modified - cluster sampling technique was used to identify a sample of 44 counties. The National 4-H Impact Assessment Instrument was used to collect the data.

Howard's study (2001) concluded that 4-H promotes feelings of self-worth, instills a sense of importance for community service and helping others, teaches members skills in decision-making and planning, and contributes to a member's sense of belonging and peer acceptance. In addition, this study indicated that residency does not affect levels of life skills gained. 
Rutherford et al. (2002) looked at the relationship between FFA Washington Leadership Conference (WLC) participants and their self-perceived leadership skills. The leadership skills studied included five scales: working with groups, understanding self, communicating, making decisions, and leadership. Self-selected respondents represented a convenience sample that consisted of 279 students. The instrument used was the Leadership Skill Inventory (LSI) developed by Townsend (1981), and refined by Townsend and Carter (1983).

Rutherford, et al. (2002) concluded that a positive relationship exists between FFA participants and self-perceptions of leadership. Specifically, level of involvement, level of activity, and holding an office all correlated positively to self-perceived leadership skills.

The purpose of a study conducted by Friesenhahn (1999) was to determine if Texas 4-H members developed leadership life skills and strengthened these skills through participation at Texas 4-H Congress. A census of participants was taken $(n=334)$. The instrument was a questionnaire adapted by Friesenhahn from previous work of Holder, Wilkinson, and Younge (1997) and Boyd (1991). The study involved a pre- and post-test containing six sections: understanding self, relating to others, communication, learning/sharing, managing and making decisions, and working with groups.

Major findings of the study conducted by Friesenhahn (1999) were that participants increased their self-esteem and self-concept, improved their ability to interact with others, strengthened their communication skills, gained more creative thinking skills, enhanced their ability to make their own decisions and manage their resources, and greatly improved their ability to effectively work in groups to accomplish group goals. 
This study showed YLLSD of Texas 4-H Congress participants, but did not evaluate the effects of years of experience or certain demographic variables.

The aforementioned studies all investigated the self-perception of youth about their leadership skills relative to their involvement in experiential youth leadership organizations or specific events within these organizations. The following studies have looked at relationships between self-perceived leadership skills of adults and their previous participation in experiential youth leadership organizations.

Brannon, Holley, and Key (1989) looked at the impact of participation in high school FFA on community involvement. A stratified random sample of Oklahoma community leaders was used $(\mathrm{n}=369)$. The researchers concluded that vocationalagriculture participants had greater involvement in community activities as adults than did non-participants.

McKinley, Birkenholz, and Stewart (1993) dealt with the experiences and characteristics that related to the leadership skills of agriculture students at the University of Missouri - Columbia. The sample contained 220 students. The instrument was a modified questionnaire originally developed by Luft (1986). Leadership abilities were categorized into four groups: interpersonal relations, administration, management of self, and communications.

McKinley et al. (1993) concluded that the communication factor was significantly correlated with student participation in 4-H and FFA. In addition, McKinley et al. (1993) found correlations between dependent variables, interpersonal relations and communication factors, and certain demographics. The researchers found the interpersonal relations factor was significantly related to age, gender, and where the 
students were raised (town or city vs. farm). The researchers further concluded the communications factor was significantly related to residence. Female, older students who were raised on farms perceived themselves to have better interpersonal relations skills. However, those students raised in a town or city perceived themselves as having better communication skills.

A study completed by Viegas (1997) evaluated a leadership curriculum developed for undergraduate family and consumer science students enrolled in an eight-week senior capstone seminar course at Iowa State University in the spring semester of 1995 . The curriculum was based on transformational leadership theory and assessed using the Leadership Practices Inventory (LPI) measuring five fundamental principles set forth by Kouzes and Posner (1987): Challenge the Process, Inspire a Shared Vision, Enable Others to Act, Model the Way, and Encourage the Heart. A pre-test and post-test were utilized to evaluate two groups of graduating seniors. The experimental group of 59 students was given instruction using the leadership curriculum. The control group was 48 students who received the traditional classroom instruction.

Viegas’ study (1997) did not show differences in LPI scores between the experimental and control groups. However, Viegas’ reports that this lack of difference may be due to an insufficient amount of time to put these skills into practice. Although, more students in the experimental group decided to change their career plans to seek a leadership position within their field than students in the control group. Viegas states the leadership curriculum may have motivated students to be more willing and likely to actively pursue leadership positions. 
A study conducted by Thorp, Cummins, and Townsend (1998) looked at a college student population. These researchers evaluated gender as it specifically related to the development of leadership skills.

Thorp et al. (1998) examined the relationship between women’s previous leadership experiences and their self-perceived leadership skills, as well as the differences between women in an all-female educational setting and women in a coeducational setting. A purposive sample of students enrolled in a collegiate academic leadership course resulted in 40 participants. The quasi-experimental design produced an all-female setting (treatment group of 20 participants) and a coeducational setting (control group of 20 participants). The instrument used was the LSI developed by Townsend and Carter (Townsend, 1981).

The researchers found statistically significant relationships between gender, participation in high school and collegiate leadership activities and participants’ selfperceived leadership skills. In addition, women in the all-female section had stronger perceptions of themselves on all five measured scales. Other researchers have confirmed that gender does play a role in students’ self-perceived youth leadership life skills development (Farley, 1989; McKinley et al., 1993; Dormody \& Seevers, 1994; Seevers \& Dormody, 1994; Wingenbach et al., 1997). 
It is important to note that other researchers have found conflicting results. Cubilla (1989) looked at characteristics of nationally recognized leaders. He found more similarities than differences between national leaders with or without 4-H backgrounds. Vail (1989) also found more similarities than differences between national leaders with and without vocational student organization backgrounds.

\section{Summary of Youth Leadership Life Skills Development}

Most of the previously mentioned research indicates that youth leadership and life skills are skills that can be developed. Many of these studies showed that youth can develop these skills through their overall participation in experiential youth leadership organizations. One study indicates the development of youth leadership and life skills over a short period during a single event while others conclude that involvement in any youth organization is positively related to YLLSD. Other studies have concluded collegiate and adult populations can develop leadership life skills and even retain the skills they develop as youth into their adult lives. 


\section{Texas 4-H Program}

The Texas 4-H program began in 1908 when T. M. (Tom) Marks, county agriculture Extension agent, started the first boys’ corn club. The club was created to teach youth new production technology that adult farmers were reluctant to adopt. Within the next few years, “pig clubs,” "beef cattle clubs,” and girls’ “tomato clubs” began. These early project-related clubs set the stage for rapid expansion of rural youth education (Texas Agricultural Extension Service, 2001).

The 4-H insignia - a four-leaf clover with an " $\mathrm{H}$ ” superimposed on each leaf- was adopted in 1911. Currently, the four H’s on the clover stand for head, heart, hands, and health. These H’s are to emphasize development of the total person: Head for intellectual development, Heart for loyalty and patriotism, Hands for service, and Health for better living. In 1919, contests became a part of the 4-H program. The next year, the motto, "To Make the Best Better,” was adopted. The year 1949 brought about the first Junior Leadership Training Program in Texas. In 1950, the first Texas 4-H Council was organized to provide a team of state officers for state leadership, which is still in place today (Texas Agricultural Extension Service, 2001).

Today, 4-H strives to develop youth into mature, competent adults. The Texas 4-H and Youth Development Program’s vision and mission are as follows:

Vision

The Texas 4-H \& Youth Development Program will continue to be a recognized leader in developing life skills, empowering youth and volunteers, and facilitating effective partnerships to create capable and responsible citizens. 
Mission

Prepare youth to meet the challenges of childhood, adolescence and adulthood, through a coordinated, long-term, progressive series of educational experiences that enhance life skills and develop social, emotional, physical and cognitive competencies. (Texas Agricultural Extension Service, 2001, p. 6)

Although times and media have changed, the Texas 4-H Program's primary focus is still teaching youth new skills and developing youth into productive and contributable members of society through hands-on experiences (Texas Agricultural Extension Service, 2001). In the 2002-2003 4-H year, there were 1,054,221 youth registered in Texas 4-H programs (Texas 4-H Office, Misty J. McCrory, personal communication, August 18, 2004).

\section{Texas FFA Association}

The National FFA Organization traces its roots back to the early 1900s. The Smith-Hughes Vocational Education Act established vocational agriculture courses in 1917. Nine years later, Henry Groseclose, a former agriculture education instructor, helped to organize the Future Farmers of Virginia for boys in agriculture classes. Soon, similar groups appeared across the country. In 1926, the American Royal Livestock Show invited vocational agriculture students to participate in National Livestock Judging Contests in Kansas City, Missouri. During the 1928 National Livestock Judging Contests, 33 students from 18 states organized to establish the Future Farmers of America to provide leadership training for high school males of vocational agriculture classes (National FFA Organization, 2003b). 
Today, the mission of the National FFA Organization is "to make a positive difference in the lives of students by developing their potential for premier leadership, personal growth, and career success through agriculture education” (National FFA Organization, 2003a).

Currently, there are 461,043 FFA members age 12 to 21 enrolled in 7,310 chapters in all 50 states, Puerto Rico, and the Virgin Islands (National FFA Organization, 2003c). During the 2003-2004 school year, there were approximately 60,400 members in Texas (Texas Education Agency, Terry Phillips, personal communication, August 18, 2004).

\section{Texas Association of Family, Career, and Community Leaders of America}

Family, Career, and Community Leaders of America (FCCLA) is a vocational student organization for high school students interested in family and consumer sciences. FCCLA is the only career and technical student organization with the family as its central focus. Projects focus on youth issues including teen pregnancy, parenting, family relationships, substance abuse, peer pressure, environment, nutrition and fitness, teen violence, and career exploration. FCCLA's mission (2003) is:

To promote personal growth and leadership development through family and consumer sciences education. Focusing on the multiple roles of family member, wage earner, and community leader, members develop skills for life through—

- character development

- creative and critical thinking

- interpersonal communication

- practical knowledge and 
- vocational preparation (Mission section, para. 1)

Currently, there are nearly 227,000 FCCLA members in 7,100 chapters across the United States (FCCLA, 2003). In the 2002-2003 academic year, there were 21,646 high school students registered in Texas FCCLA program (Texas FCCLA, Karen Matthews, personal communication, January 7, 2004).

\section{School Tour Guides}

For the purpose of this study, school tour guides refers to the 4-H, FFA, FCCLA members who impart their personal knowledge of agriculture to elementary aged students from San Antonio and surrounding area schools who request an educational tour at the San Antonio Livestock Exposition. School tour guides are not only teaching others, but also employing public speaking skills, community service efforts, and providing demonstrations.

4-H, FFA, and FCCLA members are given numerous opportunities to engage in leadership development activities. One such activity is the School Tours Program at San Antonio Livestock Exposition (San Antonio Livestock Exposition [SALE] School Tours Program, 1998).

\section{San Antonio Livestock Exposition School Tours Program}

The San Antonio Livestock Exposition (SALE) School Tours Program was created in 1990 to provide a safe, guided tour of the show grounds to students of San Antonio and the surrounding areas. Each year, about 20,000 kindergarten through third grade students are invited as guests of the School Tours Program. In order to make this possible, SALE enlists school tour guides. These guides come from 4-H clubs, FFA chapters, and FCCLA chapters from the surrounding areas. Guides are assigned a class 
for the day; the guide leads his/her class through the different barns and educational exhibits on the grounds. Before entering each barn, the guide provides background information to the students and answers any questions. Trisha Aaiontz, Co-Director of SALE School Tours Program, states that tour guides show strong leadership qualities and a willingness to give their time to serve others (SALE School Tours Program, 1998). Tanessa Saathoff, tour guide, shared that the experience helped her by requiring her to think on her feet, and she realized that it makes her feel good to teach younger children (SALE School Tours Program, 1998).

\section{Summary of Literature Review}

The previous studies found have examined whether 4-H, FFA, and FCCLA members are developing youth leadership life skills through their overall participation in these experiential youth leadership organizations. 4-H, FFA, and FCCLA members are given numerous opportunities to develop leadership skills, such as the San Antonio Livestock Exposition School Tours Program. The researcher found no independent study that addressed whether Texas 4-H, FFA, and FCCLA members are developing youth leadership life skills from their participation as school tour guides. 


\section{Purpose of the Study}

The purpose of this study is to determine if Texas 4-H, FFA, and FCCLA members develop youth leadership life skills as school tour guides. The following objectives are set to guide this study.

1. Describe the demographic characteristics of school tour guides at the 2004 San Antonio Livestock Exposition.

2. Determine if Texas 4-H, FFA, and FCCLA members are developing leadership life skills as school tour guides according to the Leadership Skills Inventory.

3. Determine which demographic variables affect youth leadership life skills development.

For the purpose of this study, leadership life skills refer to the five scales measured by the Leadership Skills Inventory: Working with Groups, Understanding Self, Communicating, Making Decisions, and Leadership. Also, for the purpose of this study, demographic variables will be defined as gender, age, ethnicity, youth organization membership, years of membership, years of experience as a school tour guide, and previous leadership skills training. 


\section{CHAPTER III \\ METHODOLOGY \\ Purpose and Objectives}

The purpose of this study was to determine if Texas 4-H, FFA, and FCCLA members developed youth leadership life skills as school tour guides. The following objectives were set to guide this study.

1. Describe the demographic characteristics of school tour guides at the 2004 San Antonio Livestock Exposition.

2. Determine if Texas 4-H, FFA, and FCCLA members developed leadership life skills as school tour guides according to the Leadership Skills Inventory.

3. Determine which demographic variables affected youth leadership life skills development.

For the purpose of this study, leadership life skills referred to the five scales measured by the Leadership Skills Inventory: Working with Groups, Understanding Self, Communicating, Making Decisions, and Leadership. Also, for the purpose of this study, demographic variables were defined as gender, age, ethnicity, youth organization membership, years of membership, years of experience as a school tour guide, and previous leadership skills training.

\section{Research Design}

Descriptive survey methodology and a correlational design were used in this study. The main advantage of this research design was that it allows "one to analyze the relationships among a large number of variables in a single study. The correlation method 
allows [one] to analyze how these variables, either singly or in combination, affect the pattern of behavior” (Gall, Borg, \& Gall, 1996, p. 414-415).

The dependent variable was youth leadership life skills development. For the purpose of this study, youth leadership life skills development (YLLSD) referred to development of skills in Working with Groups, Understanding Self, Communicating, Making Decisions, and Leadership. The independent variables were gender, age, ethnicity, youth organization membership, years of membership, years of experience as a school tour guide, and previous leadership skills training. Both the dependent and independent variables were measured following their natural occurrence.

\section{Population and Sample}

The population of interest was Texas 4-H, FFA, and FCCLA members who served as school tour guides at the San Antonio Livestock Exposition. School tour guides referred to the 4-H, FFA, FCCLA members who impart their personal knowledge of agriculture to elementary-aged students from San Antonio and surrounding area schools that requested an educational tour at the San Antonio Livestock Exposition.

The sample size was 1,691 school tour guides. All school tour guides returning for the afternoon exit-meeting during the 2004 San Antonio Livestock Exposition were asked to complete the questionnaire.

\section{Letters to Teachers and Parents}

To ensure parental consent and satisfaction of Institutional Review Board protocol, letters were sent to teachers of each participating 4-H County, FFA Chapter, and FCCLA Chapter. A cover letter was sent to all 4-H, FFA, and FCCLA sponsors requesting that an additional letter be sent home with each school tour guide for parental 
review. Parents were to review the letter before their child participated as a school tour guide. (Refer to Appendices C and D.)

\section{Instrument}

The instrument used was the Leadership Skills Inventory (LSI) developed and tested by Townsend and Carter at Iowa State University (Townsend, 1981). The LSI consisted of 21 statements describing different leadership and life skills. The instrument contained five internal scales: Working with Groups, Understanding Self, Communicating, Making Decisions, and Leadership. This instrument had consistent reliability coefficients in previous studies. For example, Williams (2003) found reliability coefficients ranging from .42 to .82; Dodson (1996) .63 to .83; Thorp (1998) .63 to .83;

Taylor (1998) .39 to .86; Bruck (1997) .46 to .82; and Boyd (1991) .59 to .84. The

following questions were categorized into the five internal scales.

\section{Working with Groups}

1. I can cooperate and work in a group

2. I get along with people around me

4. I believe in dividing the work among group members

8. I listen carefully to the opinions of the group members

12. I believe that group members are responsible persons

\section{Understanding Self}

3. I feel responsible for my actions

5 I understand myself

13. I am sure of my abilities

17. I can accept who I am

18. I feel responsible for my decisions 


\section{Communicating}

10. I can lead a discussion

14. I am a good listener

19. I can give clear directions

20. I can follow directions

\section{Making Decisions}

7. I consider all choices before making a decision

11. I use past experiences in making decisions

15. I use information in making decisions

\section{Leadership}

6. I feel comfortable teaching others

9. I am respected by others my age

10. I can lead a discussion

16. I feel comfortable being a group leader

19. I can give clear directions

21. I can run a meeting

The SPSS procedure RELIABILITY was used to compute instrument reliability

for the study. Refer to Table 1 for results. Cronbach’s alpha was reported for each scale. Reliabilities ranged from .69 to .83. The reliabilities for each scale were as follows:

Working with Groups (.74), Understanding Self (.75), Communicating (.69), Making

Decisions (.71), and Leadership (.83). 
Table 1

Reliability Coefficients (Alpha) for Each Measurement Scale

\begin{tabular}{lcc}
\hline Scale & N & Alpha \\
\hline Working with Groups & 935 & .74 \\
Understanding Self & 930 & .75 \\
Communicating & 937 & .69 \\
Making Decisions & 936 & .71 \\
Leadership & 922 & .83 \\
\hline
\end{tabular}

The instrument was modified to include selected demographic variables. These variables included gender, age, ethnicity, organization membership, and whether the participants had previous leadership training.

\section{Data Collection and Analysis}

All school tour guides that returned for the afternoon exit-meeting were asked complete the 28-item questionnaire on one of seven days: February 9, 10, 11, 12, 13, 17, and 18, 2004. The participants marked their answers on a scantron form produced by Measurement and Research Services at Texas A\&M University. Those participants who have had previous leadership training were asked to list specific examples on the back of their scantron. After participants completed the questionnaires, the researcher carefully reviewed each scantron to erase stray pencil marks, darken lightly marked responses, and evaluate for inappropriate response patterns. Student names or other personal information found on some scantrons were erased to protect the anonymity of respondents. Following this review, the scantrons were optically scanned to collect data by the Texas A\&M University Measurement and Research Services. Written answers pertaining to previous 
leadership training were grouped appropriately and entered by hand into the SPSS ${ }^{\circledR}$ software program.

Data was analyzed on a personal computer using appropriate statistical analysis using the SPSS ${ }^{\circledR} 11.5$ for Windows ${ }^{\circledR}$ software program. The SPPS ${ }^{\circledR}$ procedure RELIABILITY was used to determine the internal consistency of Part I of the instrument. Cronbach's alpha was reported for each measurement scale. Descriptive statistics to report frequencies and percentages of the independent variables were computed by the SPSS ${ }^{\circledR}$ procedure FREQUENCY. A T-test of independent means was computed for the variables of gender and previous leadership experiences. The SPSS ${ }^{\circledR}$ procedure CORRELATE was used to calculate correlation coefficients for the following variables: years as member of organization, years as a school tour guide, and previous leadership experiences. To determine differences between scales and the variables of ethnicity and organization membership, an analysis of variance (ANOVA) was computed. Tukey’s post-hoc comparison was used to locate these differences. 


\section{CHAPTER IV \\ FINDINGS AND DISCUSSION \\ Purpose and Objectives}

The purpose of this study was to determine if Texas 4-H, FFA, and FCCLA members developed youth leadership life skills as school tour guides. The following objectives were set to guide this study.

1. Describe the demographic characteristics of school tour guides at the 2004 San Antonio Livestock Exposition.

2. Determine if Texas 4-H, FFA, and FCCLA members developed leadership life skills as school tour guides according to the Leadership Skills Inventory.

3. Determine which demographic variables affected youth leadership life skills development.

For the purpose of this study, leadership life skills referred to the five scales measured by the Leadership Skills Inventory: Working with Groups, Understanding Self, Communicating, Making Decisions, and Leadership. Also, for the purpose of this study, demographic variables were defined as gender, age, ethnicity, youth organization membership, years of membership, years of experience as a school tour guide, and previous leadership skills training.

\section{Description of Sample}

The target population for this study consisted of a total of 1,691 educational school tour guides at the 2004 San Antonio Livestock Exposition that gave tours on one of seven days: February 9, 10, 11, 12, 13, 17, and 18, 2004. School tour guides were members of one of three organizations: 4-H, FFA, and FCCLA. All school tour guides 
that returned for the afternoon exit-meeting were asked complete the 28-item questionnaire. A total of 976 questionnaires were returned.

\section{Profile of Instrument}

The instrument used was the Leadership Skills Inventory (LSI) developed and tested by Townsend and Carter at Iowa State University (Townsend, 1981). The LSI consisted of 21 statements describing different leadership and life skills. The instrument contained five internal scales: Working with Others, Understanding Self, Communicating, Making Decisions, and Leadership. The instrument was modified to include selected demographic variables: gender, age, ethnicity, organization membership, and whether the participants have had previous leadership training.

Pearson Correlation Coefficients were computed to determine the intercorrelations between the leadership life skills scales. The correlation coefficients are displayed in Table 2. Davis (1971) set the following standards for describing measures of relationship: .70 or higher - very strong relationship; .50 to .69 - substantial relationship; .30 to .49 - moderate relationship; .10 to .29 - low relationship; and .01 to .09 negligible relationship. Substantial, positive relationships existed between all scale areas with the exception of three relationships, which were very strong: Working with Groups and Understanding Self (.70); Communicating and Making Decisions (.71); and Communicating and Leadership (.83). 
Table 2

Intercorrelations of Leadership Life Skills Scales

\begin{tabular}{lccccc}
\hline Scale & \multicolumn{5}{c}{ Correlation Coefficients } \\
& WWG & US & C & MD & L \\
Working with Groups & 1.00 & & & & \\
Understanding Self & .70 & 1.00 & & & \\
Communicating & .65 & .66 & 1.00 & & \\
Making Decisions & .68 & .65 & .71 & 1.00 & \\
Leadership & .61 & .62 & .83 & .58 & 1.00 \\
** Correlation is significant at the 0.01 level (2-tailed). & & & &
\end{tabular}

\section{Findings Related to Objective One}

The first objective was to describe the demographic characteristics of school tour guides at the 2004 San Antonio Livestock Exposition. The SPSS procedure FREQUENCIES was used to compute the demographic characteristics of gender, age, ethnicity, organization membership, years of membership, years as a school tour guide, and previous leadership skills training. These results are shown in Table 3. There were slightly more than twice as many female respondents as male respondents.

Questionnaires were completed by 282 males (28.9\%) and 623 females (63.8\%) and 71 (7.3\%) chose not to respond. Reported ages were as follows: 120 participants were fourteen years old or younger (12.3\%), 178 were fifteen years old (18.2\%), 233 were sixteen years old (23.9\%), 228 were seventeen years old (23.4\%), 178 were eighteen years old or older (18.2\%), and 39 chose not to respond to age (4.0\%). The largest ethnic group represented was White/Anglo with 571 respondents (58.5\%). This was followed by Hispanic with 241 respondents (24.7\%). Other reported ethnicities were as follows: 54 respondents African American (5.5\%), 46 respondents Asian American (4.7\%), 14 
respondents Native American (1.4\%), and 12 declared a mixed ethnicity (1.2\%). A total of 38 chose not to respond to ethnicity (3.9\%).

School tour guides were members of one of three groups: FFA (36.3\%), FCCLA (35.1\%), or 4-H (22.5\%). Six percent did not indicate their organization membership. Nearly half of all students have been members of their respective organization for only one to two years (47.1\%). The majority of students were first-year educational school tour guides (56.7\%). A total of 377 (38.6\%) of students indicated that they had previous leadership training experiences and 528 (54.1\%) claimed they had not; 71 did not respond. Of these 377 respondents who have had previous leadership skills experience, $117(31.0 \%)$ respondents received at least a minimum of this experience through their respective 4-H, FFA, or FCCLA program. The other 57 (15.1\%) respondents received their previous leadership skills training experience from another program.

\section{Table 3}

Selected Demographic Characteristics of School Tour Guides

\begin{tabular}{lcc}
\hline Characteristic & Frequency & Percentage \\
\hline Gender & & \\
Male & 282 & 28.9 \\
Female & 623 & 63.8 \\
Did not report & 71 & 7.3
\end{tabular}


Table 3 Continued

\begin{tabular}{|c|c|c|}
\hline Characteristic & Frequency & Percentage \\
\hline \multicolumn{3}{|l|}{ Age } \\
\hline 14 years or younger & 120 & 12.3 \\
\hline 15 & 178 & 18.2 \\
\hline 16 & 233 & 23.9 \\
\hline 17 & 228 & 23.4 \\
\hline 18 years or older & 178 & 18.2 \\
\hline Did not report & 39 & 4.0 \\
\hline \multicolumn{3}{|l|}{ Ethnicity } \\
\hline African American & 54 & 5.5 \\
\hline Asian American & 46 & 4.7 \\
\hline Hispanic & 241 & 24.7 \\
\hline Native American & 14 & 1.4 \\
\hline White/Anglo & 571 & 58.5 \\
\hline Mixed Ethnicities & 12 & 1.2 \\
\hline Did not report & 38 & 3.9 \\
\hline \multicolumn{3}{|l|}{ Organization Membership } \\
\hline $4-\mathrm{H}$ & 220 & 22.5 \\
\hline FFA & 354 & 36.3 \\
\hline FCCLA & 343 & 35.1 \\
\hline Did not report & 59 & 6.0 \\
\hline \multicolumn{3}{|c|}{ Years as Member of Organization } \\
\hline 1-2 years & 460 & 47.1 \\
\hline 3-4 years & 213 & 21.8 \\
\hline 5-6 years & 109 & 11.2 \\
\hline 7-8 years & 91 & 9.3 \\
\hline 9-10 years & 64 & 6.6 \\
\hline Did not report & 39 & 4.0 \\
\hline \multirow{2}{*}{\multicolumn{3}{|c|}{$\begin{array}{l}\text { Years as School Tour } \\
\text { Guide }\end{array}$}} \\
\hline & & \\
\hline 1 year & 553 & 56.7 \\
\hline 2 years & 212 & 21.7 \\
\hline 3 years & 88 & 9.0 \\
\hline 4 years & 43 & 4.4 \\
\hline 5 years & 38 & 3.9 \\
\hline Did not report & 42 & 4.3 \\
\hline
\end{tabular}


Table 3 Continued

\begin{tabular}{lrc}
\hline Characteristic & Frequency & Percentage \\
\hline Any Previous Leadership Experience or Training & & \\
Yes & 377 & 38.6 \\
No & 528 & 54.1 \\
Did not report & 71 & 7.3 \\
\hline
\end{tabular}

\section{Findings Related to Objective Two}

The second objective was to determine if Texas 4-H, FFA, and FCCLA members were developing leadership life skills as school tour guides according to the Leadership Skills Inventory. School tour guides were asked to respond to 21 questions in Part I of the Leadership Skills Inventory. These statements described leadership life skills and were distributed among five measurement scales. These five scales were (1) Working with Groups, (2) Understanding Self, (3) Communicating, (4) Making Decisions, and (5) Leadership.

Descriptive statistics were computed on the five measurement scales of the Leadership Skills Inventory. These data are shown in Table 4. Participants responded to each question using the following responses: $\mathrm{A}=$ Strongly Agree, $\mathrm{B}=$ Agree, $\mathrm{C}=$ Undecided, D = Disagree, and E = Strongly Disagree. For computational purposes, responses were recoded in SPSS using the following scheme: A = 5 (Strongly Agree), B $=4$ (Agree), $\mathrm{C}=3$ (Undecided), $\mathrm{D}=2$ (Disagree), and $\mathrm{E}=1$ (Strongly Disagree) .

All scales had means of 4.13 or greater, indicating that school tour guides perceived that they are developing leadership life skills through their participation as school tour guides. Working with Groups and Understanding Self had means of 4.39 and 4.40, respectively, suggesting that school tour guides perceived themselves as having a 
higher level of skills as described by these two scales than the other scales

(Communicating, Making Decisions, and Leadership). Communicating and Making

Decisions had mean scores of 4.22 and 4.23, respectively. These scores also suggest that school tour guides "agreed” with the statements for both of these scales. The Leadership scale had a mean of 4.13 suggesting that guides still "agreed" with the statements of the Leadership scale, however, to a lesser degree when compared to the other four scales.

Table 4

School Tour Guides’ Self-Perceptions of Youth Leadership Life Skills Development

\begin{tabular}{lcc}
\hline Scale & Mean $^{\mathrm{a}}$ & SD \\
\hline Working with Groups & 4.39 & .53 \\
\hline I can cooperate and work in a group & & \\
I get along with people around me & & \\
I believe in dividing the work among group members & & \\
I listen carefully to the opinions of the group members & & \\
I believe that group members are responsible persons &
\end{tabular}

Understanding Self

.55

I feel responsible for my actions

I understand myself

I am sure of my abilities

I can accept who I am

I feel responsible for my decisions

Communicating

I can lead a discussion

I am a good listener

I can give clear directions

I can follow directions 
Table 4 Continued

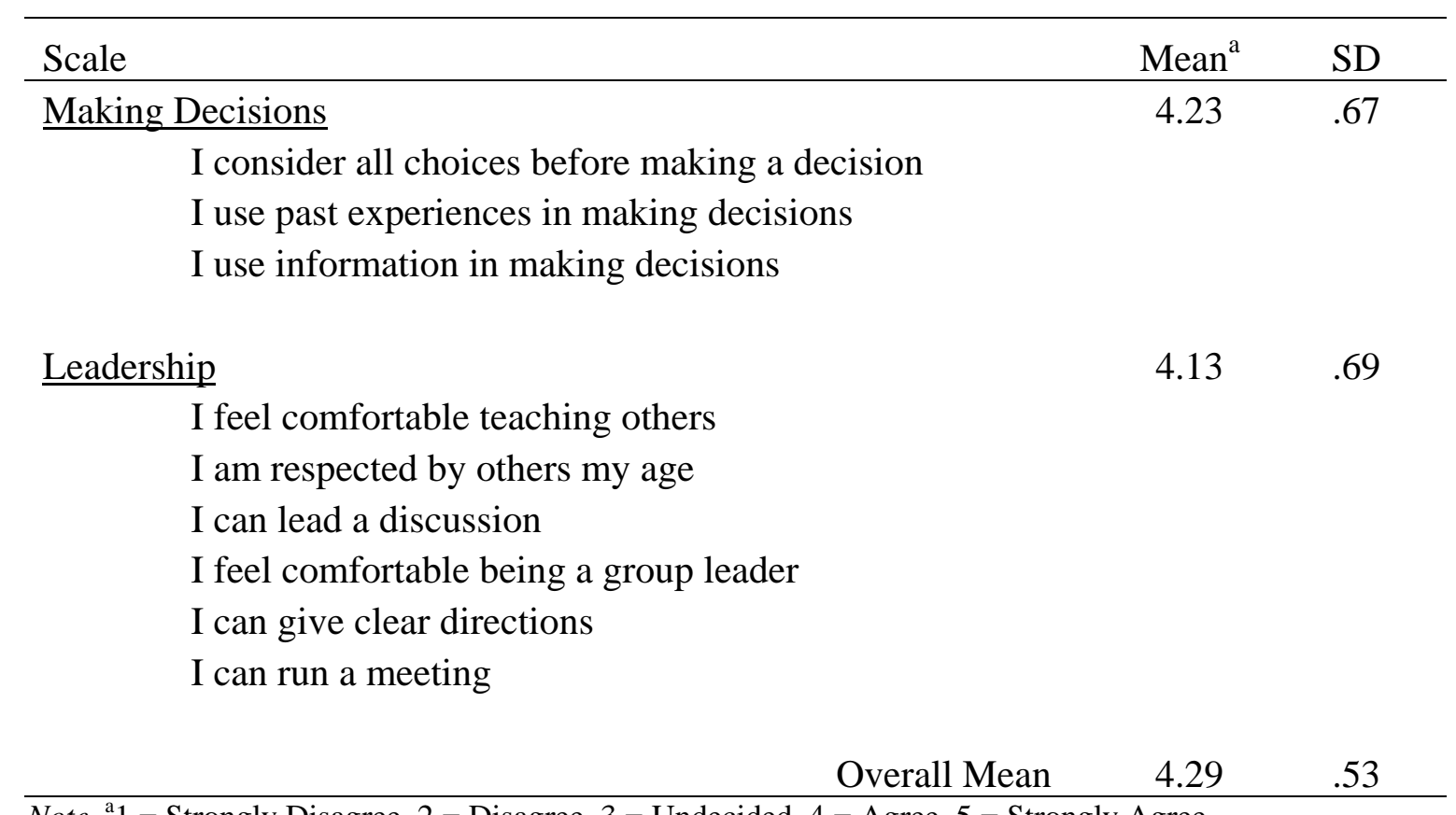

Note. ${ }^{\mathrm{a}} 1$ = Strongly Disagree, 2 = Disagree, 3 = Undecided, 4 = Agree, 5 = Strongly Agree.

\section{Findings Related to Objective Three}

The third objective was to determine which demographic variables affected youth leadership life skills development. For the purpose of this study, demographic variables were defined as gender, age, ethnicity, youth organization membership, years of membership, years of experience as a school tour guide, and previous leadership skills training.

A T-test of independent means was computed to determine if youth leadership life skills development differed by gender. A summary of these results are presented in Table 5. Statistically significant differences were found in all five scales at the 0.05 significance level. Females had a stronger perception of their abilities on all five levels than when compared to males. 
Table 5

T-test for Independent Samples: Gender and Youth Leadership Life Skills Development

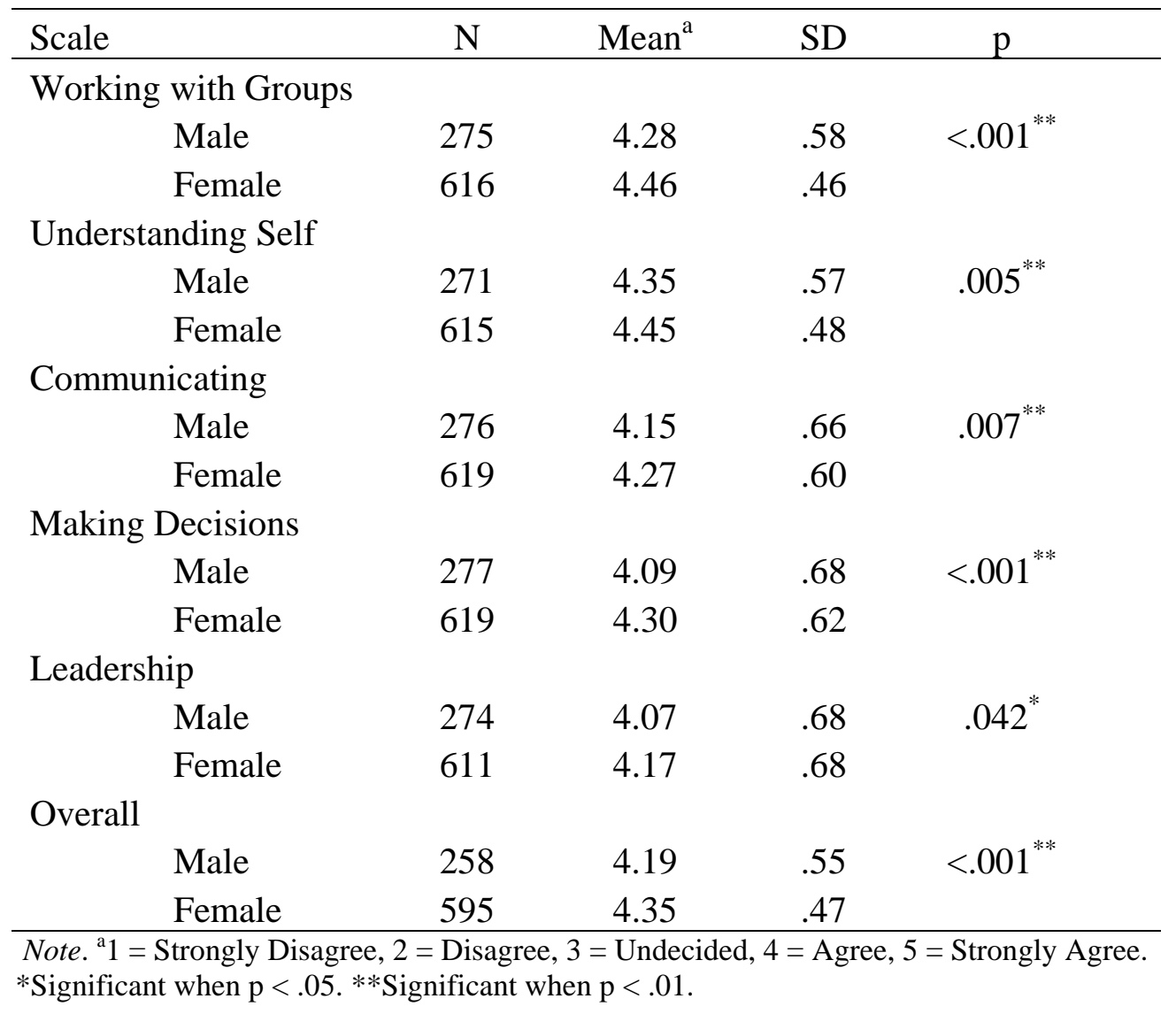

To determine if youth leadership life skills development differed by age, a Pearson correlation coefficient was computed between each of the measurement scales and age, using the procedure CORRELATE. The correlation coefficient was evaluated using a two-tailed test with a significance level of 0.05 . Table 6 presents the correlation coefficients for each of the five measurement scales.

A statistically significant correlation was found between age and the scales of Working with Groups, Understanding Self, and Communicating. These correlations coefficients were $0.078,0.071$, and 0.067 , respectively. This indicated only a negligible 
relationship between age and youth leadership life skills development. This suggests that the older the school tour guides were, the greater perception they had of the abilities to work with groups, understand themselves, and communicate. Age did not indicate a statistically significant correlation for the scales Making Decisions and Leadership.

Table 6

Pearson Correlation Coefficient between Age and Leadership Life Skills Development

\begin{tabular}{lccc}
\hline Scale & $\mathrm{N}$ & $\underline{\text { Age }}$ & $\mathrm{r}$ \\
\hline Working with groups & 921 & $.078^{*}$ & .017 \\
Understanding self & 918 & $.071^{*}$ & .032 \\
Communicating & 925 & $.067^{*}$ & .043 \\
Making decisions & 927 & .050 & .131 \\
Leadership & 912 & .048 & .150 \\
Overall & 876 & $.072^{*}$ & .034 \\
\hline Note. * Correlation is significant at the 0.05 level (2-tailed). & & & \\
\end{tabular}

To determine if youth leadership life skills development differed by ethnicity, an analysis of variance of scales was computed using the procedure ANOVA. A summary of these results are displayed in Table 7. Tukey's HSD post hoc comparison was used to detect differences among ethnic groups. Table 7 displays these results. Three scales measuring leadership life skills development were statistically different below the .05 level when grouped by ethnicity: Working with Groups, Understanding Self, and Making 
Decisions. Two scales were statistically different below the .01 level when grouped by ethnicity: Communicating and Leadership.

For the scale Working with Groups, differences were seen between African Americans and Native Americans, African Americans and Mixed Ethnicities, and Hispanics and Native Americans. African Americans had a stronger perception of their ability to work with groups than both Native Americans and those of mixed ethnicities. Hispanics also perceived themselves as having a greater ability to work with groups than Native Americans.

For the scale of Understanding Self, Native Americans differed from African Americans, Asian Americans, Hispanics, and Anglos. African Americans, Asian Americans, Hispanics, and Anglos all had stronger perceptions of their ability to understand themselves than Native Americans did.

For the scale of Communicating, Native Americans differed from both Hispanics and Anglos. Hispanics and Anglos were stronger in their perception of communicating than Native Americans.

For the scale of Making Decisions, Native Americans differed from African Americans, Asian Americans, Hispanics, and Anglos; and those of mixed ethnicities differed from Asian Americans, Hispanics, and Anglos. Asian Americans, Hispanics, and Anglos all perceived themselves better able to make decisions than both Native Americans and those of mixed ethnicities. African Americans also perceived themselves as better able to make decisions than guides from mixed ethnicities. 
For the scale of Leadership, Native Americans differed from all other ethnic

groups. All other groups had a stronger perception of their ability to lead than did Native Americans.

Overall, Native Americans differed from African Americans, Asian Americans, Hispanics, and Anglos. These four groups all had a greater perception of their leadership life skills than did Native Americans.

Table 7

Analysis of Variance of Scales Measuring Leadership Life Skills by Ethnicity

\begin{tabular}{|c|c|c|c|c|c|c|c|c|}
\hline \multirow[b]{2}{*}{ Scale } & \multicolumn{6}{|c|}{ Mean Score by Ethnicity } & \multirow[b]{2}{*}{$\mathrm{F}$} & \multirow[b]{2}{*}{ p } \\
\hline & Afr & Asian & Hisp & Nat & Anglo & Mixed & & \\
\hline Working with Groups & $4.48^{\mathrm{ac}}$ & $4.26^{\mathrm{abc}}$ & $4.42^{\mathrm{ac}}$ & $4.02^{\mathrm{b}}$ & $4.39^{\mathrm{abc}}$ & $4.03^{\mathrm{bc}}$ & 3.362 & $.005^{*}$ \\
\hline Understanding Self & $4.36^{\mathrm{a}}$ & $4.24^{\mathrm{a}}$ & $4.40^{\mathrm{a}}$ & $3.76^{\mathrm{b}}$ & $4.44^{\mathrm{a}}$ & $4.15^{\mathrm{ab}}$ & 5.649 & $<.001^{*}$ \\
\hline Communicating & $4.19^{\mathrm{ab}}$ & $4.12^{\mathrm{ab}}$ & $4.20^{\mathrm{b}}$ & $4.21^{\mathrm{a}}$ & $3.73^{\mathrm{b}}$ & $4.25^{\mathrm{ab}}$ & 2.505 & $.029^{* *}$ \\
\hline Making Decisions & $4.17^{\mathrm{ab}}$ & $4.25^{\mathrm{a}}$ & $4.26^{\mathrm{a}}$ & $3.52^{\mathrm{c}}$ & $4.24^{\mathrm{a}}$ & $3.67^{\mathrm{bc}}$ & 5.168 & $<.001^{*}$ \\
\hline Leadership & $4.16^{\mathrm{a}}$ & $4.16^{\mathrm{a}}$ & $4.22^{\mathrm{a}}$ & $4.11^{\mathrm{b}}$ & $3.49^{\mathrm{a}}$ & $4.14^{\mathrm{a}}$ & 2.682 & $.020^{* *}$ \\
\hline Overall & $4.32^{\mathrm{a}}$ & $4.25^{\mathrm{a}}$ & $4.31^{\mathrm{a}}$ & $3.74^{\mathrm{b}}$ & $4.30^{\mathrm{a}}$ & $4.00^{\mathrm{ab}}$ & 3.750 & $.002^{* *}$ \\
\hline
\end{tabular}


To determine if youth leadership life skills development differed by organization membership, an analysis of variance of the scales was computed using the procedure ANOVA. A summary of these results are displayed in Table 8. There were no statistically significant differences found at the .05 level between each youth organization.

\section{Table 8}

Analysis of Variance of Scales Measuring Leadership Life Skills Development by Organization Membership

\begin{tabular}{|c|c|c|c|c|c|}
\hline \multirow[b]{2}{*}{ Scale } & \multicolumn{3}{|c|}{ Mean Score by Organization } & \multirow[b]{2}{*}{$\mathrm{F}$} & \multirow[b]{2}{*}{$\mathrm{p}$} \\
\hline & $4-\mathrm{H}$ & FFA & FCCLA & & \\
\hline \multicolumn{6}{|l|}{ Working with } \\
\hline Groups & 4.41 & 4.34 & 4.43 & 2.998 & $<.050$ \\
\hline Understanding Self & 4.41 & 4.38 & 4.42 & 0.685 & .504 \\
\hline Communicating & 4.26 & 4.20 & 4.23 & 0.654 & .520 \\
\hline Making Decisions & 4.25 & 4.17 & 4.28 & 2.478 & .085 \\
\hline Leadership & 4.20 & 4.10 & 4.12 & 1.498 & .224 \\
\hline Overall & 4.30 & 4.25 & 4.32 & 1.648 & .193 \\
\hline
\end{tabular}

To determine if youth leadership life skills development is related to years of membership in a youth organization, a Spearman's rho correlation coefficient was computed between each of the measurement scales and years of membership, using the procedure CORRELATE. The correlation coefficient was evaluated using a two-tailed 
test with a significance level of .05. Table 9 presents a summary of the correlation coefficients for each of the five measurement scales.

A statistically significant correlation was found at the .05 level between years of membership and the scale Understanding Self. This shows a negligible relationship. A statistically significant correlation was also found at the .01 level between years of membership and the scale Making Decisions. Again, this indicates a negligible relationship with the number of years as a member. There were no statistically significant correlations seen for any of the three scales: Working with Groups, Communicating, Making Decisions, and Leadership.

Table 9

Spearman's rho Correlation Coefficient between Years as a Member of Organization and Leadership Life Skills Development

\begin{tabular}{|c|c|c|c|}
\hline \multirow[b]{2}{*}{ Scale } & \multicolumn{3}{|c|}{ Years as Member of Organization } \\
\hline & $\mathrm{N}$ & $r$ & $\mathrm{p}$ \\
\hline Working with groups & 921 & -.038 & .248 \\
\hline Understanding self & 919 & $-.079^{*}$ & .016 \\
\hline Communicating & 925 & -.033 & .321 \\
\hline Making decisions & 927 & $-.085^{* *}$ & .010 \\
\hline Leadership & 913 & .029 & .381 \\
\hline Overall & 877 & -.037 & 270 \\
\hline
\end{tabular}


To determine if youth leadership life skills development was related to years as a school tour guide, a Pearson correlation coefficient was computed between each of the measurement scales and years as a school tour guide, using the procedure CORRELATE. The correlation coefficient was evaluated using a two-tailed test with a significance level of .05. Table 10 presents the correlation coefficient for each of the five measurement scales.

The only scale that produced a significant correlation coefficient between years as a school tour guide and leadership life skills development was Understanding Self. This relationship was -0.071 , which is only a negligible relationship. There was no significant correlation was between years as school tour guide and the other four scales (Working with Groups, Communicating, Making Decisions, and Leadership).

\section{Table 10}

Pearson Correlation Coefficient between Years as a School Tour Guide and Leadership Life Skills Development

\begin{tabular}{lccc}
\hline \multirow{2}{*}{ Scale } & \multicolumn{3}{c}{ Years as a School Tour Guide } \\
\cline { 2 - 4 } Working with groups & $\mathrm{N}$ & $\mathrm{r}$ & $\mathrm{p}$ \\
Understanding self & 918 & -.022 & .512 \\
Communicating & 917 & $-.071^{*}$ & .033 \\
Making decisions & 922 & .022 & .507 \\
Leadership & 924 & -.028 & .390 \\
Overall & 911 & .053 & .110 \\
\hline
\end{tabular}

Note. *Correlation is significant at the 0.05 level (2-tailed). 
To determine if youth leadership life skills development differed by previous leadership training experiences, the researcher looked at the data in three different forms. The first was an analysis of the number of previous leadership training experiences by calculating a Pearson correlation coefficient between each of the measurement scales and the number of previous leadership training experiences (Refer to Table 11). The second analysis was simply whether the school tour guide had previous leadership training experience. A Pearson correlation coefficient was calculated between each of the measurement scales and whether the student had previous leadership experiences (Refer to Table 12.) The final analysis only took into account those school tour guides that provided examples of previous leadership experience. A T-test was used to determine if a difference existed between a previous experience in 4-H, FFA, or FCCLA (“Agricultural”) and another organization or program (“Non-Agricultural”) (Refer to Table 13).

When comparing the significance values of Tables 11 and 12, the correlation coefficients were generally higher for those students having any previous leadership experience. Therefore, it was determined the number of previous leadership experiences was not as significant as simply having any previous leadership experience. Those students having previous experience had stronger perceptions of their abilities on four of the five measurement scales: Working with Groups, Communicating, Making Decisions, and Leadership.

The final comparison was only of those school tour guides that provided examples of their previous leadership experience. These experiences were classified as ag or nonag. For the purpose of this study, agricultural experiences included those experiences 
specifically related to 4-H, FFA, or FCCLA. Non-agricultural referred to those experiences that were through another organization or program. These data are displayed in Table 13. No differences were seen between agricultural and non-agricultural experiences.

Table 11

Pearson Correlation Coefficient between Number of Previous Leadership Experiences and Leadership Life Skills Development of School Tour Guides

\begin{tabular}{lccc}
\hline \multirow{2}{*}{ Scale } & \multicolumn{3}{c}{ Number of Previous Experiences } \\
\cline { 2 - 4 } Working with groups & $\mathrm{N}$ & $\mathrm{r}$ & $\mathrm{p}$ \\
Understanding self & 935 & .054 & .096 \\
Communicating & 930 & $.103^{* *}$ & .002 \\
Making decisions & 937 & $.119^{* *}$ & $<.001$ \\
Leadership & 940 & $.100^{* *}$ & .002 \\
Overall & & & $.157^{* *}$ \\
**Correlation is significant at the 0.01 level (2-tailed). & & & \\
\end{tabular}


Table 12

Pearson Correlation Coefficient between Whether the Student Had Previous Leadership Experiences and Leadership Life Skills Development of School Tour Guides

\begin{tabular}{|c|c|c|c|}
\hline \multirow[b]{2}{*}{ Scale } & \multicolumn{3}{|c|}{ Previous Experience (Yes or No) } \\
\hline & $\mathrm{N}$ & $\mathrm{r}$ & $\mathrm{p}$ \\
\hline Working with groups & 890 & $.089^{* *}$ & .008 \\
\hline Understanding self & 890 & $.090^{* *}$ & .007 \\
\hline Communicating & 897 & $.158^{* *}$ & $<.001$ \\
\hline Making decisions & 897 & $.113^{* *}$ & .001 \\
\hline Leadership & 884 & $.204^{* *}$ & $<.001$ \\
\hline Overall & 853 & $.156^{* *}$ & $<.001$ \\
\hline
\end{tabular}


Table 13

T-test for Independent Samples: Agricultural or Non-Agricultural Previous Leadership Experiences and Leadership Life Skills Development

\begin{tabular}{ccccc}
\hline Scale & $\mathrm{N}$ & Mean & $\mathrm{SD}$ & $\mathrm{p}$ \\
\hline Working with Groups & & & & \\
Ag & 114 & 4.49 & 0.46 & .613 \\
Non-Ag & 56 & 4.53 & 0.43 & \\
Understanding Self & & & & \\
Ag & 116 & 4.55 & 0.46 & .209 \\
Non-Ag & 56 & 4.46 & 0.43 & \\
Communicating & & & & \\
Ag & 115 & 4.36 & 0.59 & .822 \\
Non-Ag & 57 & 4.38 & 0.52 & \\
Making Decisions & & & & .931 \\
Ag & 116 & 4.39 & 0.54 & \\
Non-Ag & 57 & 4.38 & 0.59 & .563 \\
Ag & & & & \\
Leadership & 115 & 4.34 & 0.67 & .867 \\
Non-Ag & 57 & 4.29 & 0.52 & \\
Overall & & & & \\
Non-Ag & 55 & 4.42 & 0.42 & \\
\hline Note. ${ }^{\mathrm{a} 1}=$ Strongly Disagree, $2=$ & Disagree, $3=$ Undecided, $4=$ Agree, $5=$ Strongly Agree
\end{tabular}




\section{CHAPTER V}

\section{SUMMARY, CONCLUSIONS, AND RECOMMENDATIONS}

\section{Summary}

The purpose of this study is to determine if Texas 4-H, FFA, and FCCLA members developed youth leadership life skills as school tour guides. The following objectives were set to guide this study.

1. Describe the demographic characteristics of school tour guides at the 2004 San Antonio Livestock Exposition.

2. Determine if Texas 4-H, FFA, and FCCLA members developed leadership life skills as school tour guides according to the Leadership Skills Inventory.

3. Determine which demographic variables affected youth leadership life skills development.

This study was designed to determine if Texas youth, who are members of 4-H, FFA, or FCCLA were developing leadership life skills as a school tour guide at the 2004 San Antonio Livestock Exposition. In addition, the researcher looked at certain demographic characteristics in comparison to the development of leadership life skills.

School tour guides were asked to complete the questionnaire after completing their tour. A daily exit meeting was held each day following the tours, and guides were asked to complete the questionnaire at this meeting. There were 1,691 school tour guides at the 2004 San Antonio Livestock Exposition. Questionnaires were completed on February 9, 10, 11, 12, 13, 17, and 18, 2004. There were 976 questionnaires returned. The questionnaire consisted of 28 questions. Part I of the survey contained 21 questions presented by Townsend (1981) measuring leadership life skills development. 
Leadership life skills development, as defined by Townsend (1981), is measured in five scales: Working with Groups, Understanding Self, Communicating, Making Decisions, and Leadership. Part II of the survey contained seven additional questions about gender, age, ethnicity, youth organization membership, years of membership, years of experience as a school tour guide, and previous leadership skills training. Those students who answered “yes” to having received previous leadership skills training were asked to provide specific examples.

Surveys were collected by the researcher and the completed scantrons were optically scanned to collect data by the Texas A\&M University Measurement and Research Services. Written answers pertaining to previous leadership training were grouped appropriately and entered by hand into the SPSS software program.

Data were analyzed on a personal computer using appropriate statistical analysis using the SPSS ${ }^{\circledR} 11.5$ for Windows ${ }^{\circledR}$ software program. Descriptive statistics were used to report frequencies and percentages of the independent and dependent variables. A Ttest of independent means was computed for the variables of gender and previous leadership experiences. Correlation coefficients were computed for the following variables: years as member of organization, years as a school tour guide, and previous leadership experiences. The procedure ANOVA was used to determine differences between each scale and the variables of ethnicity and organization membership. Tukey’s post-hoc comparison was used to locate these differences. 


\section{Conclusions and Implications}

The conclusions of this study ascertained whether school tour guides were gaining leadership life skills and identified these leadership characteristics in relation to selected demographic characteristics and previous experiences. Each conclusion will be stated, followed by the major findings that support it. Findings will be stated by objective.

\section{Conclusions Related to Objective One}

Objective 1 was to determine demographic characteristics of school tour guides at the 2004 San Antonio Livestock Exposition. These demographic characteristics included gender, age, ethnicity, youth organization membership, years as a member, years as a school tour guide, and previous leadership training experiences. The conclusions related to this objective are as follows:

1. Gender: Female respondents significantly outnumbered male respondents. Questionnaires were completed by 282 males (28.9\%) and 623 females (63.8\%).

2. Age: There were 977 respondents to age: 120 participants were fourteen years old or younger (12.3\%), 178 were fifteen years old (18.2\%), 233 were sixteen years old (23.9\%), 228 were seventeen years old (23.4\%), and 178 were eighteen years old or older $(18.2 \%)$.

3. Ethnicity: The majority of respondents were White/Anglo with 571 respondents (58.5\%). The next largest ethnic group was Hispanic with 241 respondents (24.7\%). African American, Asian American, and Native Americans claimed only a small percentage of school tour guides. Twelve guides declared a mixed ethnicity (1.2\%). 
4. Youth Organization Membership: School tour guides are members of at least one of three organizations: 4-H, FFA, and FCCLA. The participants were grouped as follows: FFA (36.3\%), FCCLA (35.1\%), or 4-H (22.5\%).

5. Years as a Member: Most school tour guides have been members of their respective organization for one to four years.

6. Years as a School Tour Guide: The majority of respondents were first-year educational school tour guides (56.7\%). About one-fourth (21.7\%) of school tour guides were participating for their second year.

7. Previous Leadership Skills Training Experience: Slightly over one-third (38.6\%) of participants indicated that they had received previous leadership skills training. The majority had not.

\section{Conclusions Related to Objective Two}

Objective 2 was to determine if school tour guides were developing youth leadership life skills according to the Leadership Skills Inventory. The conclusions related to this objective are as follows:

1. The overall mean for leadership life skill development was 4.29 indicating that school tour guides "agreed” with all statements within in the Leadership Skills Inventory. Tour guides perceived themselves as having a higher level of leadership life skill development for the scales Working with Groups (4.39) and Understanding Self (4.40) than the remaining areas. The means for Communicating (4.22) and Making Decisions (4.23) were also similar to one another. Even though guides perceived themselves as having the least development in the Leadership (4.13) scale, they still perceived themselves as developing leadership skills. 
2. If leadership life skills are being developed in one scale area, then they are also being developed in other areas due to intercorrelation(s) of the leadership life skills scales. Substantial, positive relationships existed between all scale areas with the exception of three relationships, which were very strong: Working with Groups and Understanding Self (.70); Communicating and Making Decisions (.71); and Communicating and Leadership (.83).

\section{Conclusions Related to Objective Three}

Objective 3 was to determine the demographic variables that affected youth leadership life skill development. Demographic variables were defined as gender, age, ethnicity, youth organization membership, years of membership, years of experience as a school tour guide, and previous leadership skills training. The conclusions related to this objective are as follows:

1. Females perceived themselves as having stronger leadership life skills than males in all five scales: Working with Groups, Understanding Self, Communicating, Making Decisions, and Leadership than did males. Differences in means for Working with Groups, Understanding Self, Communicating, and Making Decisions were all significant at the .01 level. Differences in means for the scale of Leadership were significant at the .05 level.

2. Negligible, positive relationships existed between age and the three scales of Working with Groups, Understanding Self, and Communicating. Correlation coefficients ranged from .067 to .078 .

3. In looking at Overall leadership life skills development, Native Americans differed from African Americans, Asian Americans, Hispanics, and Anglos. These four 
groups all indicated a stronger perception of their leadership life skills development than did Native Americans. This may be the result of cultural differences specific to Native Americans.

4. Positive relationships existed between previous leadership experiences and leadership life skills development. This indicated that participants receiving any previous leadership training experience had a higher level of leadership life skills development.

\section{Programmatic Recommendations}

The following recommendations for action are based on the findings and conclusions of this study.

1. Youth need to be encouraged to participate as school tour guides. The tour guides in this study have developed leadership life skills.

2. Males do not perceive themselves as having leadership life skills as great as females. Future 4-H, FFA, and FCCLA programs should focus on the development of leadership life skills with males to increase their self-perceptions.

3. There were over twice as many female school tour guides than male. Since this activity provided an opportunity for leadership life skills development, more males should be encouraged to participate as school tour guides.

4. Native Americans do not perceive themselves as having leadership life skills as strong as African Americans, Asian Americans, Hispanics, and Anglos. Future 4-H, FFA, and FCCLA programming should focus on the further development of leadership life skills of Native Americans.

5. For those school tour guides with previous leadership experiences, the scales of Leadership and Communicating indicated the highest levels of development. 
This suggests that educators are doing a good job in teaching these skills; however, future 4-H, FFA, and FCCLA programming should further develop students' skills in the areas of Working with Groups, Understanding Self, and Making Decisions.

6. Educators should encourage youth to participate in any activity that promotes youth leadership life skills development. This recommendation was based on the finding that school tour guides with any previous leadership experience had a greater perception of their leadership life skills than those who had not.

\section{Recommendations for Additional Research}

Based on the findings of this study the following research recommendations were proposed:

1. It is recommended to further investigate school tour guides to determine where guides are developing leadership life skills. A pre-test, post-test design may be used to determine if participation as a school tour guide is contributing to the development of leadership life skills.

2. It is recommended to investigate the reasons why female school tour guides perceived themselves as having a higher level of leadership life skills development than males.

3. Another recommendation is to investigate the differences between ethnic groups. Specifically, the researcher should look at what causes Native Americans to perceive themselves as having lower levels of leadership life skills development when compared to other groups. 
4. The relationship between participation in the previous leadership experiences should be investigated to determine which activities are contributing the most to the development of leadership life skills.

5. It is recommended to investigate why so many more females than males participate as school tour guides.

6. It is recommended that students who are not involved in extracurricular youth organizations be studied to understand the differences between members of youth organizations and other students. 


\section{REFERENCES}

Boyd, B. L. (1991). Analysis of 4-H participation and leadership life skill development in Texas 4-H club members. Unpublished doctoral dissertation, Texas A\&M University, College Station.

Boyd, B. L., Herring, D. R., \& Briers, G. E. (1992). Developing life skills in youth. Journal of Extension, 30(4). Retrieved July 7, 2003, from http://www.joe.org/joe/1992winter/a4.html

Brannon, T., Holley, C. W., \& Key, J. P. (1989). Impact of vocational agriculture/FFA on community leadership. Journal of Agricultural Education, 30(3), 37-45.

Brick, T.A. (1998). A national survey of FFA member's self-perceived leadership skills. Unpublished doctoral dissertation, Texas A\&M University, College Station.

Bruck, J.L. (1997). The influence of field dependence on college students' leadership attitudes and self-perceptions. Unpublished doctoral dissertation, Texas A\&M University, College Station.

Carter, R. I., \& Spotanski, D. R. (1989). Perceptions of leadership and personal development of selected high school students in Iowa [Electronic version]. Journal of Agricultural Education, 30(30), 30-34.

Cubilla, J. M. (1989). Characteristics of nationally recognized leaders who were members of 4-H. Unpublished master's thesis, The Ohio State University, Columbus.

Davis, J.A. (1971). Elementary survey analysis. Englewood Cliffs, NJ: Prentice Hall. Dodson, B.W. (1996). An evaluation of leadership simulation activities in the development of leadership skills in a Texas agricultural science and technology 
course. Unpublished doctoral dissertation, Texas A\&M University, College Station.

Dormody, T. J., \& Seevers, B. S. (1994). Predicting youth leadership life skills development among FFA members in Arizona, Colorado, and New Mexico [Electronic version]. Journal of Agricultural Education, 35(2), 65-71.

Family, Career, and Community Leaders of America, Inc. (FCCLA). (2003). About FCCLA. Retrieved October 23, 2003, from http://fcclainc.org/about

Farley, L.W. (1989). Gender relationships of established national leaders and their mentors. Unpublished master’s thesis, The Ohio State University, Columbus, OH.

Friesenhahn, K. (1999). An analysis of leadership life skills development at the 1998 Texas 4-H Congress. Unpublished master’s thesis, Texas A\&M UniversityKingsville, Kingsville, TX.

Gall, M. D., Borg, W. R., \& Gall, J. P. (1996). Educational research: An introduction. (6 ${ }^{\text {th }}$ edition.). White Plains, NY: Longman Publishers USA.

Holder, S., Wilkinson, R., \& Younge, J. (1997). Leadership 2000 (MSU-ES Publication No. 2174). Starkville: Mississippi State University.

Holder, S., \& Wilkinson, R. (2001). Leadership 2001 (MSU-ES Publication No. 2200). Starkville: Mississippi State University.

Howard, J. W. (2001). Impact assessment of the Texas 4-H and youth development program. Unpublished doctoral dissertation, Texas A\&M University, College Station.

Kouzes, J.M., \& Posner, B.Z. (1987). The leadership challenge. San Francisco, CA: Jossey-Bass. 
Kouzes, J.M. \& Posner, B.Z. (1995). The leadership challenge: How to keep getting extraordinary things done in organizations. San Francisco, CA: Jossey-Bass Publishers.

Luft, V. D. (1986). Leadership ability of young rural adults in North Dakota (Project No. ND4901). Fargo: North Dakota State University, Agricultural Experiment Station.

Lundy, J. L. (1986). Lead, follow, or get out of the way: Leadership strategies for the thoroughly modern manager. San Diego, California: Avant Books.

McKinley, B. G., Birkenholz, R. J., \& Stewart, B. R. (1993). Characteristics and experiences related to the leadership skills of agriculture students in college. Journal of Agricultural Education, 34(3), 76-83.

Miller, R. A. (1976). Leader/agent's guide: Leadership life skills. Stillwater: Oklahoma State University.

National FFA Organization (2003a). The FFA Mission \& Strategies. Retrieved July 19, 2003, from http://www.ffa.org/about_ffa/organization/html/mission.html.

National FFA Organization (2003b). Key Moments in FFA History. Retrieved July 19, 2003, from http://www.ffa.org/about_ffa/organization/html/history.htm

National FFA Organization (2003c). FFA Key Statistics. Retrieved July 19, 2003, from http://www.ffa.org/about_ffa/organization/html/ffa.html.

Northouse, P. G. (2004). Leadership: Theory and practice (3rd ed.). Thousand Oaks, CA: Sage Publications, Inc.

Rosenbach W. E. \& Taylor, R. L. (1993). Contemporary issues in leadership. Boulder, CO: Westview Press. 
Rutherford, T. A., Townsend, C. D., Briers, G. E., Cummins, R., \& Conrad, C. R. (2002). Leadership self-perceptions of WLC participants [Electronic version]. Journal of Agricultural Education, 43(2), 22-33.

San Antonio Livestock Exposition school tours program [Motion picture]. (1998). United States.

Seevers, B. S., \& Dormody, T. J. (1994). Predicting youth life leadership skills development among senior 4-H members: A tri-state study [Electronic version]. Journal of Agricultural Education, 35(3), 63-69.

Seevers, B. S., Dormody, T. J., \& Clason, D. L. (1995). Developing a scale to research and evaluate youth leadership life skills development. [Electronic version]. Journal of Agricultural Education, 36(2), 28-34.

Taylor, J.E. (1998). Leadership skills and attitudes perceived by collegiate male students. Unpublished doctoral dissertation, Texas A\&M University, College Station.

Texas Agricultural Extension Service. (2001). Texas 4-H Management System: County Management Guide (4-H Publication No. 1-5.059). College Station, TX: Texas A\&M University

Thorp, L., Cummins, R., \& Townsend, C. (1998). Women’s self-perceived leadership skills in a collegiate agricultural education course. Journal of Agricultural Education, 39(1), 55-62.

Townsend, C. (1981). FFA participation and personal development as perceived by Iowa vocational agriculture seniors. Unpublished doctoral dissertation, Iowa State University, Ames. 
Townsend, C. D., \& Carter, R. I. (1983). The relationship of participation in FFA activities and leadership, citizenship, and cooperation. Journal of the American Association of Teacher Educators in Agriculture, 24(1), 20-25.

Vail, A. (1989). Gender relationships of established national leaders and their mentors. Unpublished master's thesis, The Ohio State University, Columbus.

Viegas, S. M. (1997). Leadership development curriculum for family and consumer sciences undergraduates. Unpublished doctoral dissertation, Iowa State University, Ames.

White, R.T. (1997). Family and consumer sciences life skills: Attainment by secondary school students. Unpublished doctoral dissertation, Iowa State University, Ames.

Williams, J. (2003). The intellectual capacity of leadership competencies as perceived by past members of a collegiate sophomore leadership course. Unpublished master's thesis, Texas A\&M University, College Station.

Wingenbach, G. J., \& Kahler, A. A. (1997). Self-perceived youth leadership and life skills of Iowa FFA members [Electronic version]. Journal of Agricultural Education,38(3), 18-27. 
APPENDIX A

LEADERSHIP SKILLS INVENTORY QUESTIONNAIRE 


\section{INFORMATION SHEET Development of Youth Leadership Life Skills of Texas 4-H and FFA members as agriculture education guides}

You have been asked to participate in a research study about the development of your leadership skills. You are just one of about 3,000 students that have been chosen to participate. You were chosen because you were a school tour guide at the San Antonio Livestock Exposition. The purpose of this study is to determine if you developed leadership skills from being a school tour guide. This research is for the completion of the thesis project by Laura Real.

If you agree to participate in this study, all you have to do is complete a 28-question survey. It will only take you about 10 minutes to complete and you will only have to answer it once. You understand that there are no risks or benefits associated with completing this survey.

If there is any question that makes you feel uncomfortable, you do not have to participate in the study. If for any reason you decide not to participate in this survey, that is your right and it shall be respected. If you do not participate, you understand that it will not affect your grades or standing within the 4-H or FFA programs. Your participation in this study is voluntary. You can stop your participation at anytime. You understand that all information you provide is kept strictly anonymous. Do not put any identifying marks on the survey.

If you have any questions about the survey, you may contact Laura Real, Graduate Assistant, at (979) 845-5198 (lreal@aged.tamu.edu) or Dr. Julie Harlin, Assistant Professor, at (979) 862-3014 (j-harlin@tamu.edu).

You understand that this research study has been reviewed and approved by the Institutional Review Board - Human Subjects in Research, Texas A\&M University. For research-related problems regarding subjects’ rights, you can contact the Institutional Review Board through Dr. Michael W. Buckley, Director of Research Compliance, Office of Vice President for Research at (979) 458-4067 (mwbuckley@tamu.edu).

You have read and understand the explanation provided to you. You have had all your questions answered to your satisfaction. By completing the survey, you understand that you are consenting to participate. You have been given a copy of this form. 


\section{Leadership Skills Inventory}

Thank you for participating in this study! Please do not put any identifying marks on the scantron. We would like to know if you believe you have developed leadership skills by participating as a school tour guide at San Antonio Livestock Exposition. Your responses will be combined with the others; there will be no way to identify you with your answers. Please only use a No. 2 pencil and fill in bubbles completely.

Part I. Respond to each of the following statements based on your experience as a school tour guide at the San Antonio Livestock Exposition. Fill in the scantron with the appropriate letter that corresponds to what you think.

1. I can cooperate and work in a group.

2. I get along with people around me.

3. I feel responsible for my actions.

4. I believe in dividing the work among group members.

5. I understand myself.

6. I feel comfortable teaching others.

7. I consider all choices before making a decision.

8. I listen carefully to opinions of group members.

9. I am respected by others my age.

10. I can lead a discussion.

11. I use past experiences in making decisions.

12. I believe that group members are responsible persons.

13. I am sure of my abilities.

14. I am a good listener.

15. I use information in making decisions.

16. I feel comfortable being a group leader.

17. I accept who I am.

18. I feel responsible for my decisions.

19. I can give clear directions.

20. I can follow directions.

21. I can run a meeting.
Strongly

Agree

A

A

A

A

A

A

A

A

A

A

A

A

A

A

A

A

A

A

A

A

A
Agree

Undecided

Disagree

Strongly

Disagree

$\begin{array}{lllll}\text { A } & \text { B } & \text { C } & \text { D } & \text { E } \\ \text { A } & \text { B } & \text { C } & \text { D } & \text { E } \\ \text { A } & \text { B } & \text { C } & \text { D } & \text { E } \\ \text { A } & \text { B } & \text { C } & \text { D } & \text { E } \\ \text { A } & \text { B } & \text { C } & \text { D } & \text { E } \\ \text { A } & \text { B } & \text { C } & \text { D } & \text { E } \\ & \text { B } & \text { C } & \text { D } & \text { E } \\ \text { A } & \text { B } & \text { C } & \text { D } & \text { E } \\ \text { A } & \text { B } & \text { C } & \text { D } & \text { E } \\ \text { A } & \text { B } & \text { C } & \text { D } & \text { E }\end{array}$

A B

C

D

E

B

C

D

E

B

C

D

E

C

C

D

E

B

B

C

D

E

D E

D E

B

C

C

D

D

C

C

C

\section{$\mathrm{E}$} $\mathrm{E}$ E E

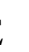
E E E E E 
Part II. Please refer to spaces 22-28 to answer to following questions.

22. What is your gender?
a. Male
b. Female

23. What is your age?
a. 14 years or younger
b. 15 years old
c. 16 years old
d. 17 years old
e. 18 years or older

24. Which best describes you?
a. African American
b. Asian American
c. Hispanic
d. Native American
e. White/Anglo

25. Today, I am representing:
a. 4-H
b. FFA
c. FCCLA

26. How many years have you been a member of the 4-H, FFA, or FCCLA program (including this year)?
a. $1-2$ years
b. $3-4$ years
c. $5-6$ years
d. $7-8$ years
e. 9-10 years

27. How many years have you been a school tour guide at San Antonio Livestock Exposition (including this year)?
a. 1 year
b. 2 years
c. 3 years
d. 4 years
e. 5 or more years

28. Have you had any leadership training before your participation as a school tour guide? If yes, please list specific examples on the back of your scantron.
a. Yes
b. No

Thank you for taking time to complete this very important survey! Please return your questionnaire, completed scantron, and pencil to the front table. 
APPENDIX B

LETTERS TO SAN ANTONIO LIVESTOCK EXPOSITION

ADMINISTRATIVE OFFICE AND

SCHOOL TOURS COMMITTEE 
January 21, 2004

San Antonio Livestock Exposition

Attn: Administrative Office

Keith Martin

P.O. Box 200230

San Antonio, TX 78220-0230

Dear Mr. Martin:

I am a graduate student at Texas A\&M University in the Department of Agricultural Education. For partial completion of my Masters degree, I am required to conduct research in an effort to complete a thesis. Currently, I am an intern in the livestock office at the San Antonio Livestock Show. For my research and a as it related to SALE, I am interested in determining if school tour guides are developing leadership life skills.

I would like to collect data through the duration of SALE. Through this collection, I will provide students with an information sheet explaining my study. The tour guides will complete a 28-question survey at the afternoon meeting following their tours. The questionnaire should take no more than 10 minutes for completion and guides will only complete it once. To ensure anonymity of participants, the participants' names will not be collected on the questionnaire or on any other form. Attached are the survey questions, a copy of a sample scantron that will be used, and the information sheet.

Prior to the show, I would like to send a letter to the county Extension agents and teachers responsible for the guides. I was hoping to send the letter in the packet of information that is sent by the School Tours Committee in January. Attached to this letter would be another letter to be sent home to the parents of the school tour guides. These letters would include the purpose and procedure of my study. Attached you will find these letters.

Recently, the Institutional Review Board (IRB) at Texas A\&M University approved my study. All attached material and procedures have been approved by the IRB.

I have high hopes for this study. I am really interested in knowing if these 4-H, FFA, and FCCLA members are developing leadership life skills through their participation as school tour guides. I think it would be great to know that not only are elementary students learning more about agriculture, but also that high school students are gaining leadership life skills at the same time.

If you have any questions, please feel free to contact me by email (lreal@aged.tamu.edu), at work (210) 225-0575, or at home (830) 914-2833. 
Thank you for your cooperation,

Laura A. Real

Masters Candidate

Department of Agricultural Education

114 Scoates Hall, TAMU

College Station, TX 77843-2116

Attachments

cc: Karla Friesenhahn

Keith Martin 
January 21, 2004

San Antonio Livestock Exposition

Attn: School Tours Committee

Scott Sorrell

P.O. Box 200230

San Antonio, TX 78220-0230

Dear Mr. Sorrell:

I am a graduate student at Texas A\&M University in the Department of Agricultural Education. For partial completion of my Masters degree, I am required to conduct research in an effort to complete a thesis. Currently, I am an intern in the livestock office at the San Antonio Livestock Show. For my research and a as it related to SALE, I am interested in determining if school tour guides are developing leadership life skills.

I would like to collect data through the duration of SALE. Through this collection, I will provide students with an information sheet explaining my study. The tour guides will complete a 28-question survey at the afternoon meeting following their tours. The questionnaire should take no more than 10 minutes for completion and guides will only complete it once. To ensure anonymity of participants, the participants' names will not be collected on the questionnaire or on any other form. Attached are the survey questions, a copy of a sample scantron that will be used, and the information sheet.

Prior to the show, I would like to send a letter to the county Extension agents and teachers responsible for the guides. I was hoping to send the letter in the packet of information that is sent by the School Tours Committee in January. Attached to this letter would be another letter to be sent home to the parents of the school tour guides. These letters would include the purpose and procedure of my study. Attached you will find these letters.

Recently, the Institutional Review Board (IRB) at Texas A\&M University approved my study. All attached material and procedures have been approved by the IRB.

I have high hopes for this study. I am really interested in knowing if these 4-H, FFA, and FCCLA members are developing leadership life skills through their participation as school tour guides. I think it would be great to know that not only are elementary students learning more about agriculture, but also that high school students are gaining leadership life skills at the same time.

If you have any questions, please feel free to contact me by email (lreal@aged.tamu.edu), at work (210) 225-0575, or at home (830) 914-2833. 
Thank you for your cooperation,

Laura A. Real

Masters Candidate

Department of Agricultural Education

114 Scoates Hall, TAMU

College Station, TX 77843-2116

Attachments

cc: Karla Friesenhahn

Keith Martin 


\section{APPENDIX C}

\section{COVER LETTER TO TEACHERS}




\section{Memorandum}

Date: January 2004

To: County Extension Agents, Agricultural Science Teachers, FCCLA Sponsors

From: Laura A. Real

Masters Candidate

Agricultural Education

114 Scoates Hall, TAMU

College Station, TX 77843-2116
Dr. Julie Harlin

Assistant Professor

Agricultural Education

119B Scoates Hall, TAMU

College Station, TX 77843-2116

\section{RE: $\quad$ Parent Information Letter}

At the 2004 San Antonio Livestock Exposition, a research study will be conducted to determine if youth are gaining leadership skills by participating as a school tour guides. This research is for the completion of the thesis project by Laura Real.

Attached you will find a letter addressed to the parents of the San Antonio Livestock Exposition school tour guides. Please distribute to the appropriate parents before the show begins. Please feel free to make any necessary copies.

Thank you for your help. 
APPENDIX D

LETTER TO PARENTS OF SCHOOL TOUR GUIDES 
January 2004

Dear Parent(s) of School Tour Guide:

Your child will be asked to participate in a research study about the development of his/her leadership skills. He/She is just one of about 3,000 students that have been chosen to participate. Your child was chosen because he/she will be a school tour guide at the San Antonio Livestock Exposition. The purpose of this study is to determine if school tour guides develop leadership skills by participating as guides. This research is for the completion of the thesis project by Laura Real.

If your child agrees to participate in this study, all he/she will have to do is complete a 28question survey. It will only take about 10 minutes to complete and will only have to be answered once. There are no risks or benefits associated with completing this survey.

If there is any question that makes your child feel uncomfortable, he/she does not have to participate in the study. If for any reason your child decides not to participate in this survey, that is his/her right and it shall be respected. If your child does not participate, it will not affect grades or standing within the 4-H, FFA, or FCCLA programs. Participation in this study is voluntary. You or your child can stop participation at anytime. All information your child provides is kept strictly anonymous. There will be no identifying marks on the survey.

If you have any questions about the survey, you may contact Laura Real, Graduate Assistant, at (979) 845-5198 (lreal@aged.tamu.edu) or Dr. Julie Harlin, Assistant Professor, at (979) 862-3014 (j-harlin@tamu.edu).

This research study has been reviewed and approved by the Institutional Review Board Human Subjects in Research, Texas A\&M University. For research-related problems regarding subjects' rights, you can contact the Institutional Review Board through Dr. Michael W. Buckley, Director of Research Compliance, Office of Vice President for Research at (979) 458-4067 (mwbuckley@tamu.edu).

Please keep a copy of this form for your records.

Sincerely,

Laura A. Real

Masters Candidate

Agricultural Education

114 Scoates Hall, TAMU

College Station, TX 77843-2116
Dr. Julie Harlin

Assistant Professor

Agricultural Education

119B Scoates Hall, TAMU

College Station, TX 77843-2116 
APPENDIX E

INSTITUTIONAL REVIEW BOARD APPROVAL 
December 12, 2003

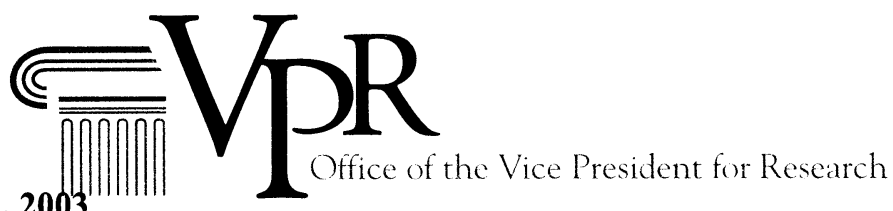

\section{MEMORANDUM}

TO:

Ms. Laura Real

Department of Agricultural Education

MS 2116

FROM: $\quad$ Dr. Gaile S. Cannella, Chair

Institutional Review Board

MS 1112

SUBJECT: IRB Protocol Review

Title: "Development of Youth Leadership Life Skills of Texas Youth as San Antonio Livestock Exposition School Tour Guides"

Protocol Number: 2003-0533

Review Category: Full Review

Approval Date: December 10, 2003 - December 09, 2004

The approval determination was based on the following Code of Federal Regulations: 45 CFR 46 Subpart A. The research involves children and was, therefore, examined against provisions of Subpart D of 45 CFR 46, particularly 46.404 (Research not involving greater than minimal risk) and 46.408 (Requirements for permission by parents or guardians and for assent by children), as well as the current guidelines for inclusion of children in research. The IRB found the research to be of minimal risk to the child, and after considering the age, maturity and psychological state of the children to be enrolled in this study, determined that adequate provisions are made for soliciting the assent of the child and permission of a parent or legally authorized guardian who has been granted authority to consent for medical care including research.

Remarks: After specific review, it has been determined that approval for waiver of the requirement to obtain signed informed consent may be granted under 45 CFR 46.117(c). However, a study information sheet with all elements of consent must be provided to study participants.

The Institutional Review Board - Human Subjects in Research, Texas A\&M University has reviewed and approved the above referenced protocol. Your study has been approved for one year. As the principal investigator of this study, you assume the following responsibilities:

Renewal: Your protocol must be re-approved each year in order to continue the research. You must also complete the proper renewal forms in order to continue the study after the initial approval period.

Adverse events: Any adverse events or reactions must be reported to the IRB immediately.

Amendments: Any changes to the protocol, such as procedures, consent/assent forms, addition of subjects, or study design must be reported to and approved by the IRB.

Informed Consent/Assent: All subjects should be given a copy of the consent document approved by the IRB for use in your study.

Completion: When the study is complete, you must notify the IRB office and complete the required forms. 


\section{VITA}

Laura Ann Real

15492 Real Rock Road

Marion, Texas 78124

Biographical:

Education:

Professional Experience:
Born September 3, 1980 in San Antonio, Texas

B.S., Animal Science, Texas A\&M University, 2003

M.S., Agricultural Education, Texas A\&M University, 2004

Graduate Teaching Assistant, Department of Agricultural Education,

Texas A\&M University

Fall 2003, Summer 2004

Livestock Management Intern, San Antonio

Livestock Exposition,

San Antonio, Texas

Spring 2004

4-H Summer Intern, Texas Cooperative Extension - Comal and Guadalupe Counties,

New Braunfels and Seguin, Texas

Summer 2001

Summer Program Development Intern, Texas Pork Producers Association,

Austin, Texas

Summer 2000 